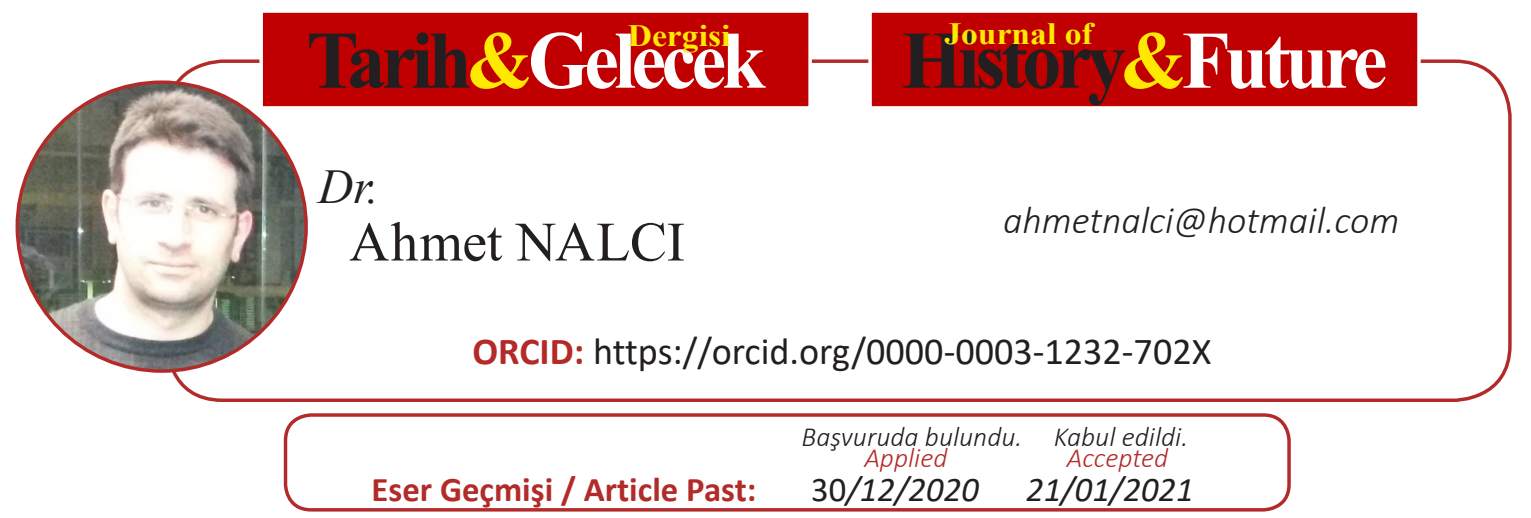

Araştırma Makalesi

DOI: http://dx.doi.org/10.21551/jhf.850064

Research Paper

Orjinal Makale / Orginal Paper

\title{
Osmanlı Eğitiminde Modernleşme Gayretlerinin Taşraya Yansıması: Adıyaman, Besni ve Kâhta Erkek Rüşdiyeleri Örneği
}

\author{
Reflection of Modernization Efforts in Ottoman Education to the \\ Country: Example of Adryaman, Besni and Kâhta Male Rushdiye \\ Schools
}

Öz

Osmanlı Devleti, 18 ve 19. yüzyıllarda yaşadığı sarsıntılardan sonra her alanda 1slah ve modernleşme girişiminde bulunma gereksinimi duymuştur. Bu alanların başında ise yeni bir nesil inşa etme konumunda bulunan eğitim gelmektedir. Öncelikle başkentte başlayan eğitimi modernleştirme çalışmaları, bilhassa 1869 tarihli Maarif-i Umumiye Nizamnamesi’nden sonra taşraya yansımaya başlamıştır. Bu çalışmaların taşrada görüldüğü ilk alan ise orta dereceli okul seviyesinde olan rüşdiyeler olmuştur.

Rüşdiye mekteplerinin açıldığ 1 bölgelerden birisi de 19. yüzyılın sonları ve 20. yüzyılın başlarında Mamuratülaziz vilayetinin Malatya sancağına bağlı durumda bulunan Hısnımansur, Besni ve Kâhta kazalarıdır. Günümüzde Adıyaman ili sınırları içinde kalan bu üç kaza merkezinde açılan rüşdiye mektepleri, bölgenin modern okullar ile tanışmasını sağlamıştır. Çalışmamızda bu rüşdiye mekteplerinin kuruluş ve faaliyetleri incelenerek modern eğitim konusundaki problemler ve bu problemlere karş1 üretilen çözüm yolları değerlendirilmiştir.

Anahtar Kelimeler: Eğitim Tarihi, Osmanlı Devleti, Modernleşme, Adıyaman, Rüşdiye.

\begin{abstract}
The Ottoman Empire felt the necessity to attempt improvement and modernization in every field after the turmoil happened in the 18th and 19th centuries. One of these fields is education, which is a leading position to build a new generation. The modernization studies of education, which started especially in the capital, started reflecting to the provinces after the 1869 Education Regulation. The first
\end{abstract}


area where these studies were seen in the provinces was Rushdiye schools referred to secondary school.

Some of the regions where Rushdiye schools were opened are the Hisnimmansur, Besni and Kâhta districts, which were dependent on Malatya sanjak of the Mamuratülaziz province in the late 19th and early 20th century. The secondary schools opened in these three city centers within the borders of Adiyaman today enabled the region to meet modern schools. In our study, the establishment and activities of these secondary schools are examined and the problems in modern education and the solutions to these problems are evaluated.

Keywords: History of Education, Ottoman Empire, Modernization, Adiyaman, Rüshdiye.

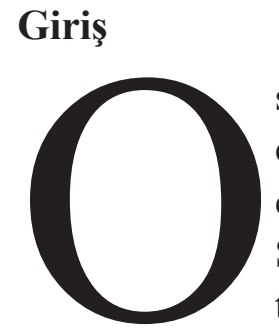

smanlı Devleti'nin 19. yüzyılda gerçekleştirdiği modernleşme hamlelerinin en önemli alanlarının başında şüphesiz eğitim gelmektedir. Sivil anlamda eğitimde modernleşme çabalarına ise rüşdiye mektepleri ile başlanılmıştır. Sıbyan mekteplerinin üstünde yüksekokullara hazırlayıcı bir kurum olarak tasarlanan rüşdiye mekteplerinin ilki II. Mahmud Dönemi'nde açılan "Mekteb-i Maarif-i Adli" olarak kabul edilmektedir. Hem devlet memuru yetiştirmek hem de mevcut memurların niteliklerini yükseltmek hedefleri ile kurulan bu mektep modern manadaki ilk orta dereceli sivil okuldur' 1847 yılında Mekatib-i Umumiye Nazırı Kemal Efendi'nin İstanbul'da pilot olarak iki rüşdiye mektebi açması, bunlardan müspet neticeler alınması üzerine İstanbul'un farklı semtlerinde 5 adet yeni rüşdiye mektebi tesis edilmesi ve 1848 y1lında rüşdiye mekteplerine öğretmen yetiştirmek amacıyla Darulmuallimin'in açılması rüşdiye mekteplerinin gelişimini hızlandıran gelişmeler olmuştur ${ }^{2}$.

Rüşdiye mekteplerinin taşra sathına yayılabilmesi ise daha çok 1869 tarihli Maarif-i Umumiye Nizamnamesi'nin yayımlanmasından sonra gerçekleşebilmiştir. $\mathrm{Bu}$ nizamnamede rüşdiye mekteplerinin plan, program ve ders müfredatının çerçevesi belirlenmiştir³ . 1877-78 Osmanl1Rus Harbi yayılmayı olumsuz etkilese de 1880'li yıllarda hem evkaf-1 münderisenin ${ }^{4}$ maarife

1 Bayram Kodaman, Abdülhamid Devri Eğitim Sistemi, TTK, Ankara, 1999, s. 92; Mahmud Cevat İbnu'ş Şeyh Nafi, Maarif-i Umumiye Nezareti Tarihçe-i Teşkilat ve İcraatı-XIX. Asır Osmanlı Maarif Tarihi(Haz. Taceddin Kayaoğlu), Yeni Türkiye Yayınları, Ankara, 2001, s. 24.

2 Ali Akyıldız, Tanzimat Dönemi Osmanlı Merkez Teşkilatı'nda Reform, Eren Yayıncılık, İstanbul, 1993, s. 236-237; M. Cevad, age, s. 34-36; Selçuk Akşin Somel, Osmanlı'da Eğitimin Modernleşmesi (18391908), İletişim Yayınları, İstanbul, 2015, s. 65.

3 Muammer Demirel, “Türk Eğitiminin Modernleşmesinde Rüşdiye Mektepleri”, Türkler, C. 15, Yeni Türkiye Yayınları, Ankara, 2002, s. 79; M. Cevat, age, s. 427-429; Kodaman, age, s. 93.

4 Evkaf-1 münderise, hayat şartlarının değişmesiyle amaçları ortadan kalkan, yararlananları kaybolan ve gelirleri sarf olunacak hayır müesseseleri mevcut olmayan vakıflar için kullanılan bir kavramdır. Osmanlı yöneticileri, tahsis edildiği hayır müesseseleri mevcut olmayan, bir tarafa şart edilmemiş bulunan ve yararlananları ortadan kaybolmuş olduğundan fırsatçılara yem haline gelmiş olan vakıfların gelirlerine yeni bir yön vermeyi uygun bulmuşlard1. Böylece bu gelirlerden eğitim gibi önemli bir alanda yararlanma imkânı oluşturulmuştu; Yakup Karataş, "Sultan II. Abdülhamid'in Eğitim Politikalarının Mali Bir Veçhesi: Evkaf-1 Münderisenin Maarife Terki”, Atatürk Üniversitesi Türkiyat Araştırmaları Enstitüsü Dergisi (TAED), Say1: 57, Erzurum, 2016, (ss. 1839-1867), s. 1841. 
kazandırılması hem de alınan vergilerden maarife ayrılan oranın artırılması rüşdiyelerin yayılmasını hızlandırmıştır ${ }^{5}$ Nitekim II. Abdülhamid Devri'nin sonlarına doğru imparatorluk genelindeki

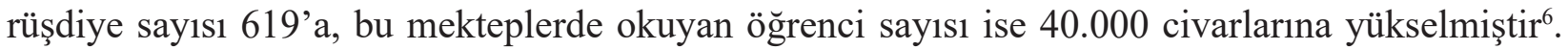
Çalışmamızın kapsadığı yıllarda Malatya Sancağı'na bağlı olan Adıyaman (Hısnımansur), Besni ve Kâhta kazalar1 ${ }^{7}$ da bu dönemde rüşdiye mektebi ile tanışarak modern eğitimin ulaştığ yerleşim yerlerinden olmuştur. Besni'de 1871, Adıyaman'da 1874', Kâhta'da ise 1882 yılında ${ }^{9}$ rüşdiye mektebi açılmıştır.

Bu çalışmada Adıyaman, Besni ve Kâhta rüşdiyeleri incelenerek Osmanlı Devleti’nin 19. yüzyılın son dönemlerinde başlattığı eğitimde modernleşme girişiminin taşrada hangi ölçüde hayata geçirilebildiği tartışılacaktır. Tarihsel yöntemin tercih edildiği bu çalışma ile modern eğitimin önündeki problemler saptanacak; eğitimin bina, öğrenci, öğretmen, ders araç gereci gibi her bir boyutuyla ilgili değerlendirme yapılacaktır.

\section{Adıyaman (Hısnımansur) Rüşdiye Mektebi}

Adıyaman'da bir rüşdiye mektebi açılmasıyla ilgili ilk karar 1870 yılında Diyarbekir valiliği tarafından alınmıştır ${ }^{10}$. Bu kararın akabinde, 1871-72 (H. 1288) yılı Diyarbekir Salnamesi'nde mektebin ismi yer almaktadır ve bu durum okulun açıldığına işaret etmektedir ${ }^{11}$. Rüşdiye'nin resmî

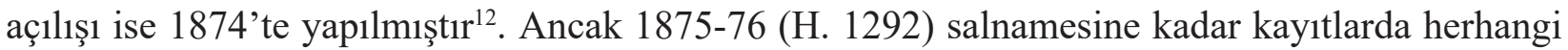
bir muallim ismi yer almamıştır. Buradan anlaşılan, açılan okulun uzun bir süre muallimsiz kaldığı veya yerel çabalarla istihdam edilen kadrosuz bir muallim tarafından idare edildiğidir. İhtimal, okulun bunca yıl resmî olarak açılamama sebebi, bir muallim ve bevvaba maaş verecek ve okulun masraflarını karşılayacak bir gelir kaynağı oluşturulamamasıdır. Nitekim okula ilk atanan muallim olan Şeyh Mehmed Efendi'nin tayini ile ilgili bir belgede ${ }^{13}$, tayin ile beraber maaşlarıyla ilgili kaynak sorunun da nasıl çözülmüş olduğu görülmektedir. Bunun sonucunda, muallim ve bevvap

5 Rüşdiye mekteplerinin taşrada yayılması konusunda en büyük problemlerin başında gelen finans sorunu ve bunun aşılması için yapılan maarif yetkililerinin ürettiği çözümler için bkz. Ahmet Nalcı, Doğan Gün, "Modernleşme Yolunda Osmanlı Devleti Maarifinin Finansman Sorunu: Malatya Rüşdiyesi Örneği”, History Studies, C. 10, S. 1, Şubat 2018, (101-123).

6 Kodaman, age, s. 105.

7 Adıyaman, Besni ve Kâhta kazalarının bu çalışmanın zaman kapsamına tekabül eden dönemindeki idari taksimatı için bkz. Ahmet Nalcı, Osmanlı Modernleşme Dönemi'nde Malatya'da Eğitim (1869-1919), Yayımlanmamış Doktora Tezi, Mersin Üniversitesi, Sosyal Bilimler Enstitüsü, 2020, s. 46-52.

8 Maarif-i Umumiye Nezareti Celilesi İdaresinde Bulunan Mekatib-i İbtidaiye, Rüşdiye, I'dadiye, Aliye ile Mekatib-i Hususiye ve Ecnebiyyenin ve Dersaadet'te Tahriri İcra Kılınan ve Taşrada Mevcud Bulunan Kütübhanelerin İstatistiği (1310-1311), Dersaadet, Matbaa-i Amire, s. 39-40.

9 Sâlnâme-i Vilâyet-i Mamûratülaziz (SVM), H. 1301, s. 95.

10 Diyarbekir Gazetesi (16 Şubat 1871)'den aktaran Talip Atalay, Diyarbekir Vilayeti'nde Hısnımansur, Kâhta ve Besni, Medeniyetler Kavşağı Adıyaman Sempozyumu (8-10 Eylül 2006), Adıyamanlılar Vakfı Yayınları, Adıaman, 2008, s. 168.

11 Sâlnâme-i Vilâyet-i Diyarbekir (SVD), (H. 1288), s. 126.

12 Maarif İstatistiği 1310-1311, s. 40.

13 Buna göre öğrencisi az olduğundan muallim-i saniliği lağv edilen Kudüs Mektebi Rüşdiyesi mualliminin maaşı, yerel idare tarafından Hısnımansur muallim-i sanisi olarak seçilen Şeyh Mehmed Efendi'ye; Bosna vilayetine bağlı Akhisar'ın sıbyan mektebine dönüştürülen rüşdiye mektebi muallim maaşından 80 kuruşun da, mahalli idare tarafından seçilecek olan bevvaba maaş olarak verilmesi kararlaştırılmıştır; BOA. MF. MKT., 475/58 (02 S. 1291/22 Mart 1874). 
maaşlarına kaynak bulunmuş, muallim olarak görevlendirilen Şeyh Mehmed Efendi'ye 110 kuruş $^{14}$ okulun masrafları için ise zuhurat tertibinden yıllık 600 kuruş tahsis edilmiştir. Böylelikle okul, 1874-75 (H. 1291) yılında 25 öğrenci ${ }^{15}$ ile Musalla Caddesinde ${ }^{16}$ eğitim-öğretim hayatına başlamıştır. Okul öğrencileri için Maarif Nezareti'nden istenen kitap, harita ve risaleler de 1875 ve 1876 yıllarında merkezden gönderilmiştir ${ }^{17}$.

1878 yılında Muallim-i Sani Mehmed Efendi vefat etmiş yerine imtihan sonucunda Seyyid Efendi geçmiş ve "numune hatt yazısı" da merkeze gönderilmiştir ${ }^{18}$. Malatya Rüşdiyesi Muallimi Ebubekir Efendi gibi Mehmed Efendi'nin de görevi başında vefat etmesi kayda değerdir. Seyyid Efendi'nin gayretleriyle öğrenci mevcudunda bir kıpırdanma olmuştur. Mektebin öğrenci sayıs1 1881 'de 26 iken, 1882 ve 1883 yıllarında 31'e ve 1884 yılında 35'e yükselmiştir'19.

Buna rağmen, yıllar geçtiği halde Hısnımansur Rüşdiyesi'nin tam olarak istenen seviyeye getirilememesi nezaret ve vilayette problem olmuştur. Bu duruma yol açan en büyük nedenin bu yıllardaki öğretmen yetersizliği yanında, Hısnımansur halkının da okula yeterli ilgiyi göstermemiş olduğu anlaşılmaktadır. Kasaba zenginleri okulun önemini yeterince takdir edemeyip çocuklarını göndermede yeterli istek göstermemekte, fakirlerin ise çalıştırmak yerine çocuklarını okula gönderme imkânına sahip olmamaları okula ilgiyi azaltmaktadır. Ayrıca yöredeki erken evlenme ve yüksek başlık paraları gibi faktörler de sermaye sağlamak üzere insanları erken yaşlarda çalışmaya zorlamakta, çocuklar rüşdiyeye devam edecekleri yaşta gelecek planlarına hazırlık yapmak zorunda kalmaktalard1 ${ }^{20}$. Okulun açılışından itibaren 15 yıl geçmiş olmasına rağmen öğrenci sayısının 30 civarlarında seyretmesi Nezaret'in dikkatini çekmiştir. 1889 yılına ait bir belgede Kâhta, Hekimhan, Keban Ma'deni ve Besni ile birlikte Hısnımansur rüşdiyelerinde beklenen gelişmelerin olmadığından bahisle buralarda kaçar hane ve sıbyan mektebi olduğu bilgilerinin gönderilmesi istenmiştir ${ }^{21}$. Maarif Nezareti bu bölgelerdeki hane ve sıbyan mektebi sayısını istemiştir ki, hedeflenen gelişmeyi gösteremeyen rüşdiyelerden yeterli hane ve sıbyan mektebi sayısı olmayan

14 BOA. MF. MKT., 17/3, (28 Z. 1290/18 Şubat 1874); Bu belgede, dikkat çeken bir unsur da maaş1 Hısnımansur Rüşdiyesi muallimine aktarılan Kudüs Rüşdiyesi muallim-i sanisi Muhsin efendi ile ilgilidir. Muhsin Efendi görevini layıkıyla yapmamakta, hareketleri beğenilmemekte ve yapılan uyarları da dinlememektedir. Buna rağmen bu vakte kadar görevine devam etmiş olması ise Müftü efendinin akrabası olduğundandır. Ama artık yerinin değiştirilmesi “vücub-ı kat'i” bir hal almıştır; bkz. agb. Görüleceği üzere, tanıdık ve hatır-gönül ilişkilerinin devrede olmadığı bir zaman dilimine rastlamak çok zordur.

15 SVD, (H. 1292), s. 129; Sâlnâme-i Devlet-i Aliyye (SDA), (H. 1292), s. 158; Salname kayıtları bir önceki yıla ait olduğundan 1291 yılını esas aldık. Ayrıca, tebliğinde Hısnımansur Rüşdiyesi’nin açılışına yer veren Atalay, bu konuda şunları yazmıştır: “Salname kayıtlarına göre 5 yıl boyunca, yani 1870'ten 1876 yılına kadar öğretmen ataması yapılamadı. 1876 yılında ilk öğretmen ataması yapılarak 30 öğrenci ile öğretime başladı.”; Talip Atalay, agm, s. 169. Büyük olasılıkla Atalay, bizim yukarıdaki dipnotlarda verdiğimiz kaynakları görmemiştir.

16 SVM, H. 1312, Nüfus Nezareti Kısmı, s. 20; Said Öztürk, "Osmanlı Döneminde Adıyaman'ın Sosyal ve Ekonomik Özellikleri”, Medeniyetler Kavşağı Adlyaman Sempozyumu (8-10 Eylül 2006), Adıyamanlılar Vakfı Yayınları, Adıyaman, 2008, s. 142.

17 BOA. MF. İBT., 9/22, (6 Za. 1293/23 Kasım 1876); BOA. MF. İBT., 9/59, (13 Za. 1293/28 Kasım 1876); BOA. MF. MKT., 27/197, (28 Ra. 1291/4 May1s 1875).

18 BOA. MF. MKT., 41/42, (17 B. 1293/7 Ağustos 1876).

19 BOA. MF. İBT., 20/19, (21 C. 1319/5 Ekim 1901).

20 Atalay, agm, s. 169.

21 BOA. MF. MKT.,., 105/90, (26 Ca. 1306/28 Ocak 1889). 
rüşdiyelerin lağvına, diğerlerinin de ıslahına karar verilebilsin. Nitekim bu görüşmelerden sonra Kâhta Rüşdiye Mektebi'nin lağvedilmesine karar verilmiş, okulun Muallim-i Sanisi Mehmed Efendi ise Hısnımansur Rüşdiye Mektebi muallim-i saniliğine tayin olmak istediğini vilayet maarif müdürlüğüne bildirmiştir ${ }^{22}$. Bu arada, Besni Rüşdiyesi Muallim-i Sanisi Hüseyin Efendi de maaşının yeterli olmadığı ve havasına uyum sağlayamadığı gerekçesiyle Hısnımansur muallim-i saniliğine tayin istemiş; ancak daha önce gelen talepler olduğu için kendisine olumsuz cevap verilmiştir ${ }^{23}$.

1890 yılında, Mamuratülaziz Valisi, Maarif Nezareti'ne yazdığı yazıda bu yörelerdeki okulların büyük beklentilerle açıldığını ve ıslah edilmeleri gerektiğini ifade etmiştir. Şimdiye kadar istenen seviyede olmasa bile rüşdiye mektebinin yöre halkının aydınlanmasına yardımcı olduğunu dile getiren Vali, Hısnımansur muallim-i saniliğine de Mustafa Efendi'nin tayin edilmesini talep etmiştirir ${ }^{24} 1890$ (H. 1307) Salnamesinden de anlaşıldığı kadarıyla bu göreve Mustafa Efendi getirilmiştir ${ }^{25}$. Yukarıda geçtiği üzere Hısnımansur muallimliğine birçok talip olmuştu. Mustafa Efendi'nin bu göreve atanması, yerel idarecilerin onay verdiği isimlerin merkezce de tasdik edildiği anlamı taşımaktadır.

1890'lı yıllar Hısnımansur Rüşdiyesi’nin en verimli yılları olarak dikkat çekmektedir. Bunda en büyük etken, nezaretin ıslah çalışmaları ile birlikte Kâhta Rüşdiyesi'nin kapatılması ve bunun neticesinde bu bölge öğrencilerinin Hısnımansur Rüşdiyesi'ne kayması olmuş olmalıdır. Zira 1890'da 35 olan öğrenci sayıs1 1891 'de bir anda 50 oluvermiştir ${ }^{26}$. Öğrenci sayısı artınca, Hısnımansur kazası idarecileri, muallim-i saninin artık tüm derslere yetişemediğini ve rika dersine vakti kalmadığını ifade ederek okula bir rika mualliminin tayin edilmesi lazım geldiğini belirtmişlerdir. Ancak gelen cevapta şu an -100 kuruşluk dahi olsa- yeni bir muallime maaş verilecek bütçe olmadığı söylenmiş, maaş sorununa mahalli olarak çözüm bulunduğu takdirde, bir rika mualliminin göreve başlamasının uygun olacağı söylenmiştir ${ }^{27}$. Dolayısıyla rika mualliminin göreve başlaması gecikmiştir.

Okulun öğrenci sayısının artışı ile birlikte Şakir Efendi, muallim-i evvel olarak tayin edilmiş ancak okulda kısa bir süre görev yapmıştır ${ }^{28}$. Salnamedeki rakamlarla birebir uyuşmasa da Maarif Nezareti İstatistikleri okul hakkında bize önemli bilgiler vermektedir. Bu istatistiklere göre 1893 yılında öğrenci sayısı 52'ye yükselmiştir. 1894-95 y1lı ile 1895-96 yılı verileri karşılaştırıldığında okula yeni dâhil olanların ve okulu terk edenlerin sayısındaki büyük farklılık dikkat çekmektedir. 1894-95 yılında okula yeniden dâhil olan öğrenci sayısı 19, yıl içinde okulu terk eden sayı ise 13 iken 1895-96 yılında okula dâhil olan 3, terk eden de yine 3'tür. 1894-95 yılında diploma almayı hak eden öğrenci sayısı 11, gelecek yıla devren kalan öğrenci sayısı 47 iken 1895-96 yılında diploma almayı başaran öğrenci sayısı 4 olmuş, neticede gelecek yıla devreden öğrenci sayısı 43

22 BOA. MF. MKT., 113/41, (19 S. 1307/14 Ekim 1889).

23 BOA. MF. MKT., 113/91, (6 Ra. 1306/10 Kasım 1888). Belgenin tarihi Başbakanlık Devlet Arşivleri’nin kataloglarında bu şekilde verilmiş, ancak yazışmalar daha sonraki tarihlerde -R. 10-19 Teşrin-i Evvel 1305/18-27 Ekim 1889- yapılmıştır.

24 BOA. MF. MKT., 117/56, (18 Ş. 1307/30 Mart 1890).

25 SVM, H. 1307, s. 61.

26 SVM, H. 1308, s. 65; SVM, H. 1310, s. 119. Salname bilgilerin geçen yılı gösterdiği unutulmamalıdır.

27 BOA. MF. MKT., 127/49, (14 Ş. 1308/25 Mart 1891).

28 SVM, H. 1310, s. 119. 
olmuştur. Memur ve öğretmen sayısı 1894-95 yılında 1 iken $1895-96$ yılında 2'ye yükselmiştir ${ }^{29}$. $\mathrm{Bu}$ artış muallim Cemal Efendi'nin göreve başlamasıyla ilgili olmalıdır. Zira kayıtlarda, Ahmed Cemal Efendi'nin 10 Kasım 1896 (29 Teşrinievvel 1312) tarihinde 85 kuruş maaşla Hısnımansur Kazası Mekteb-i Rüşdiyesi hüsn-i hat muallimliğine tayin olduğu kaydedilmiştir ${ }^{30}$.

Öğrenci sayısı 1897'de kendi zirvesini görmüş ve 59 olmuştur ${ }^{31}$. Bu durum karşısında Hısnımansur Kaymakamlığı, Maarif Nezareti'ne bir arzuhal yazarak Muallim-i Sani Mustafa Avni Efendi'nin muallim-i evvel olmasını talep etmişlerdir. Yaklaşık sekiz senedir okulda ikinci öğretmen olarak bulunan Mustafa Avni'den 'iffet ve istikamet sahibi fart-ı himmet ve mezid-i liyakat ki hassail-i merğube ile behiyy'ül-emsali temyiz ve tehayyüz etmiş ve ma'lumat-l ilmiye ve fenniyesinden dolayı da cidden en ali sitayişlere seza bulunmuş olan mekermetlü Mustafa Avni Efendi" diye bahseden kaza idarecileri, okulun gelişerek öğrenci sayısının 60'a kadar yükselmesinde Mustafa Avni Efendi'nin yaptığı gayretli çalışmaların ve teşviklerin etkili olduğunu belirtmişlerdir. $\mathrm{Bu}$ girişten sonra Mustafa Avni Efendi'nin "kendi hizmet-i vakısını takdiren ve kendisini taltifen muallim-i evvelliğe terfi' ve ta'yin” edilerek bu kaza muallim-i evveliğine mahsus 500 kuruşluk maaşın maarif bütçesine dâhil edilmesini istemişler; bu sayede muallimin perişanlıktan ve sefaletten kurtulacağını ifade etmişlerdir. Maarif-i Umumiye Nezareti ise verdiği cevapta, Mustafa Avni Efendi'nin mahallince seçilen muallim-i sanilerden olduğunu ve Darülmuallimin mezunu olmadığını, dolayısıyla muallim-i evvelliğe terfiinin mümkün olmadığını söyleyerek eski maaşıyla istihdam edilmesi gerektiğini belirtmiştir ${ }^{32}$. Satır aralarından anlaşıldığ kaza idarecilerinin Mustafa Avni Efendi’yi bu göreve getirmek istemelerinin sebebi, bir makam tevdi etmekle birlikte muallim maaşının da artmasını sağlamaktır. Ancak bu yıllarda maarifin en büyük sorunu ülkenin yaşadığg mali zorluklardır. Bu durum da haliyle taşraya yansımakta, eğitim

29 Maarif Umumiye Nezareti Celilesi İstatistiki (1310-1311), s. 40; Maarif-i Umumiye Nezareti İstatistiki (1311-1312), Darul-Hilafetül'Aliyye, Matbaa-i Amire, s. 41; Hülasa defterlerindeki rakamlar da Maarif İstatistikleri ve salnameleri büyük oranda doğrulamaktadır. Örneğin 1894-1895 yılına ait 4 farklı 3 aya ait hülasa defterinde öğrenci sayıs1 50, 44, 52, 55; BOA. MF. İBT., 37/45, (13 Z. 1311/17 Haziran 1894); BOA. MF. İBT., 39/113, (14 Ra. 1312/15 Eylül 1894); BOA. MF. İBT., 41/10, (18 C. 1312/17 Haziran 1312); BOA. MF. İBT., 43/88, (16 N. 1312/13 Mart 1895); 1895-1896 y1lında 54; BOA. MF. İBT., 51/8, (29 L. 1313/13 Nisan 1896); 1901-1902 ders yılında 55’tir; BOA. MF. İBT., 115/15, (15 Z. 1319/25 Mart 1902). Bu rakamlara göre okulun ortalama öğrenci mevcudunu hesapladığımızda karşımıza 51,6 rakamı çıkmaktadır. Ayrıca bkz. Tablo 1. (Hısnımansur Rüşdiyesi Personeli ve Öğrenci Sayısı). Bununla birlikte hülasa defterlerinin hazırlanıp düzenli olarak merkeze gönderilmesinde sorunlar yaşandığı anlaşılmaktadır. Zira 1878 yılında, Diyarbekir vilayetine gönderilen yazıda Hısnımansur ile birlikte Mardin rüşdiyesi öğrenci devam durumlarının merkeze ulaştığı, ancak bundan sonra merkezden gönderilen "matbu' jurnal varaka hülasa cedveli"nin" muntazaman doldurulması gerektiği ifade edilmiştir; BOA. MF. MKT., 56/15, (29 R. 1295/2 Mayıs 1878). 1879 yılında ise nezaret doğrudan Hısnımansur Rüşdiyesi muallimini muhatap alarak bir yazı göndermiştir. Bu yazıda başkente ulaşan öğrenci devam jurnallerinde öğrenci sayısıyla, sınıfları ve dersleri gösterilmemiş olduğunu ve bundan sonra hangi sınıflarda kaç öğrencinin okuduğunu ve hangi derslerin okutulduğu bilgilerinin tam doldurulması gerektiğini bildirmiştir; BOA. MF. MKT., 63/106, (26 B. 1296/16 Temmuz 1879).

30 Ramazan Çelem, Sicill-i Ahval Defterlerine Göre Malatya Doğumlu Memurlar (1879-1909), Yayımlanmamış Yüksek Lisans Tezi, Gaziosmanpaşa Üniversitesi, Sosyal Bilimler Enstitüsü, 2014, s. 125; BOA. MF. İBT., 60/20, (17 Za. 1314/19 Nisan 1897). Bahsi geçen Ahmed Cemal Efendi, Maarif Salnamesinde Cemal Efendi olarak zikredilmiştir; bkz. Sâlnâme-i Nezâret-i Maârif-i Umûmiye (SNMU), H. 1316, s. 1171.

31 SNMU, H. 1316, s. 1171.

32 BOA. MF. MKT., 364/60, (10 Ra. 1315/9 Ağustos 1897). 
öğretimi de olumsuz olarak etkilemektedir. Öğretmen maaşları da bu durumdan nasibini almaktadır. Muallimler arasındaki statü farklılığı da maaşlara aksetmekte rika muallimi, muallim-i sani'den; muallim-i sani de muallim-i evvelden düşük maaş almaktadır. Dolayısıyla, kaymakamlık, Mustafa Avni’yi muallim-i evvelliğe terfi' ettirerek fakir ve perişan haline son vermeyi arzu etmiştir.

Okul, böylece, 1900'lü yıllara Mustafa Avni Efendi’nin muallim-i saniliğiyle girmiştir. Abdülhamid devrinin sonu yaklaşırken Mustafa Avni Efendi, Keban Rüşdiyesi'ne atanmış ${ }^{33}$, yerine ise 1906-1907 ders yılında Hacı Hüseyin Efendi geçmiştir ${ }^{34}$. Aşağıdaki tablo rüşdiye mektebinin II. Abdülhamid devrindeki durumunu yansitmaktadır:

Tablo 1. II. Abdülhamid Yıllarında Hısnımansur (Adıyaman) Rüşdiyesi Personeli ve Öğrenci Say1s1

\begin{tabular}{|c|c|c|c|c|c|}
\hline Yll & M. evvel & M. sani & Rika M. & Bevvab & Talebe \\
\hline $1875-1876^{1}$ & & Şeyh Mehmed Ef. & & & 25 \\
\hline $1876-1877^{2}$ & & Şeyh Mehmed Ef. & & $\begin{array}{c}\text { Mehmed Ali } \\
\text { Ef. }\end{array}$ & 30 \\
\hline $1877-1878^{3}$ & & Şeyh Mehmed Ef. & & $\begin{array}{l}\text { Mehmed Ali } \\
\text { Ef. }\end{array}$ & 30 \\
\hline $1883-1884^{4}$ & & & & & 33 \\
\hline $1884-1885^{5}$ & & Seyyid Ef. & & Ali Ef. & 34 \\
\hline $1885-1886^{6}$ & & Seyyid Ef. & & Ali Ef. & 34 \\
\hline $1886-1887^{7}$ & & & & & 35 \\
\hline $1887-1888^{8}$ & & & & & 25 \\
\hline $1888-1889^{9}$ & & Seyyid Ef. & & Ali Ef. & 30 \\
\hline $1890-1891^{10}$ & & Mustafa Ef. & & Ali Ef. & \\
\hline $1891-1892^{11}$ & & Mustafa Ef. & & Ali Ef. & 35 \\
\hline $1892-1893^{12}$ & Şakir Ef. & Mustafa Ef. & & Ali Ef. & 50 \\
\hline $1894-1894^{13}$ & Şakir Ef. & Mustafa Ef. & & Ali Ef. & 55 \\
\hline $1898-1894^{14}$ & & Mustafa Ef. & Cemal Ef. & & 59 \\
\hline $1899-1900^{15}$ & & Mustafa Ef. & Cemal Ef. & & 49 \\
\hline $1900-1901^{16}$ & & Mustafa Ef. & $\begin{array}{c}\text { Ahmed Cemal } \\
\text { Ef. }\end{array}$ & & 52 \\
\hline $1901-1902^{17}$ & & Mustafa Ef. & $\begin{array}{c}\text { Ahmed Cemal } \\
\text { Ef. }\end{array}$ & & 44 \\
\hline $1903-1904^{18}$ & & Mustafa Ef. & Cemal Ef. & & 57 \\
\hline $1907-1908^{19}$ & & Hacı Hüseyin Ef. & & Hüseyin Ef. & 54 \\
\hline
\end{tabular}

Meşrutiyet yılları Hısnımansur Rüşdiyesi’nin hem artık muallim-i evvele hem de yeni bir

33 BOA. MF. İBT., 191/93, (1 Ca. 1325/12 Haziran 1907); BOA. MF. MKT., 1002/40, (14 Ca. 1325/25 Haziran 1907).

34 SNMU, H. 1321, s. 652; SVM H. 1325, s. 99. 
binaya kavuşacağı yıllar olacaktır. Meşrutiyet' in ilk yılı olan 1908'de halen Hacı Hüseyin Efendi'nin muallim-i sani olarak görevinde devam ettiği anlaşılmaktadır ${ }^{35} .1909$ yılında ise muallim-i sani olarak Mehmed Habib Efendi görevi devralmıştır ${ }^{36}$.

1909-1910 ders yılında bir taraftan yeni rüşdiye mektebi binası yapımının ihalesine gidilirken ${ }^{37}$ diğer yandan da Vilayet Maarif Müdürlüğü'nden Maarif Nezareti'ne yazılar yazılarak 3.000 hanelik kasabalarındaki rüşdiyeye bir muallim-i evvel tayin olunmasını, diğer türlü çocukların eğitimden yeterince "müstefid olamadığını" dile getirmişlerdir ${ }^{38}$. Maarif Nezareti de bu isteği makul karşılamış, nihayet 1912 yılında bir muallim-i evvel tayin edilmiştir. Bu muallim 1883 doğumlu Darülmuallimin-i İbtidaiye mezunlarından Mustafa Efendi'dir. Mustafa Efendi burada aylık 500 kuruş maaş alacaktır. Mustafa Efendi'nin yardımcılığını ise Muallim-i Sani Ahmed Efendi yapacaktır. 1893 doğumlu ve idadi çıkışlı olan Ahmed Efendi'nin alacağı aylık ise 300 kuruştur. Okulun artık ayrı bir hat muallimi vardır. Ömer Mazhar Efendi ismindeki bu muallim ise 1877 doğumlu olup aylık ücreti 100 kuruştur ${ }^{39}$. I. Dünya Savaşı yılları yaklaşırken rüşdiye mektebi bu eğitim kadrosu ${ }^{40}$ ve yenilenmiş mektep binası ${ }^{41}$ ile eğitim öğretime devam etmektedir.

Tablo 2. II. Meşrutiyet Yıllarında Hısnımansur Rüşdiye Mektebi’nin Öğrenci Mevcudu

\begin{tabular}{|l|c|c|c|c|c|}
\hline \multicolumn{1}{|c|}{ Yıl } & Mülazimat & 1. Sınıf & 2. sınıf & 3. sinıf & Toplam \\
\hline $1908^{20}$ & 20 & 12 & 8 & 3 & 43 \\
\hline $1908-1909^{21}$ & 11 & 20 & 11 & 8 & 50 \\
\hline $1909^{22}$ & 16 & 21 & 11 & 8 & 56 \\
\hline $1909-1910^{23}$ & 22 & 21 & 8 & 6 & 57 \\
\hline $1912^{24}$ & & 18 & 12 & 14 & 44 \\
\hline $1912-1913^{25}$ & & 20 & 12 & 8 & 40 \\
\hline
\end{tabular}

Tabloda dikkat çeken en önemli husus "mülazemet" diye ayrı bir sınıf oluşturulmasıdır. 1909 y1lında muallim-i sani olarak görev yapan Mehmed Habib Efendi bu durumu kasabada resmî bir ibtidai mektebi olmaması, dolayısıyla rüştiyeye gelen öğrencilerin çoğunun okuma-yazmada zorlanmasıyla ortaya çıkan ihtiyaç ile açıklamıştır ${ }^{42}$. Bu durumun Hısnımansur' da ibtidai açılıncaya

35 BOA. MF. İBT., 230/1, (6 Ra. 1327/28 Mart 1909).

36 BOA. MF. İBT., 238/48, (16 B. 1327/3 Ağustos 1909); BOA. MF. İBT., 245/50, (14 N. 1327/29 Eylül 1909).

37 Yapılan münakasa ile bina inşa bedeli 22.000 kuruş belirlenmiştir; Mamuratülaziz Gazetesi, $30 \mathrm{Z}$. 1327/12 Ocak 1910.

38 BOA. MF. İBT., 238/48, (16 B. 1327/3 Ağustos 1909); BOA. MF. İBT., 262/59, (4 S. 1328/15 Şubat 1910); BOA. MF. İBT., 344/67, (1 Za. 1329/24 Ekim 1911).

39 BOA. MF. İBT., 350/17, (6 Z. 1329/28 Kasım 1911); BOA. MF. İBT., 357/3, (28 M. 1330/18 Ocak 1912); 1890'lardan sonra taşra rüşdiyelerinde muallim-i evvel olacakların Darülmuallimin-i rüşdi mezunu olmaları veya 6 yıl muallim-i sanilik deneyimden sonra maarif nezareti bünyesinde yapılacak sınav sonucuna göre göreve getirilmeleri şartı getirilmişti; bkz. Nurdoğan, agt, s. 274.

40 Mustafa ve Ahmed Efendi 1913 yılında da aynı görevlerinde devam etmektelerdir; BOA. MF. MKT., 1188/52, (29 Ş. 1331/3 Ağustos 1913); Hat muallimi Ömer Mazhar Efendi de 1913-1914 eğitim öğretim yılında aynı görevde devam etmektedir; BOA. MF. İBT., 483/26, (19 Ra. 1332/15 Şubat 1914).

41 Okulun yeni binasının maliyeti 19.315 kuruş olmuştur; BOA. MF. İBT., 402/15, (29 Za. 1330/9 Kasım 1912). Rüşdiye mektebinin planı için bkz. Ek 1.

42 BOA. MF. İBT., 217/103, (20 Za. 1326/14 Aralık 1908). 
kadar $^{43}$ devam etmesi, Mehmed Habib Efendi'yi doğrulamaktadır. Bunun yanında tabloda verdiğimiz 6 farklı hülasa defterinden elde ettiğimiz sonuçlara göre bir ortalama hesapladığımızda okul mevcudu 48,3 olarak çıkmaktadır. II. Abdülhamid döneminde bu rakam 51,6 olarak çıkmıştı ${ }^{44}$. Dolayısıyla buradan öğrenci mevcudunun çok büyük değişikliğe uğramadığı ancak yine de II. Abdülhamid Devri'nde bu sayının daha yüksek olduğu değerlendirmesini yapabiliriz. Ayrıca yine tutulan imtihan çizelgeleri incelendiğinde öğrencilerin hepsinin erkek olduğu ve -bu ayrıma sadece Hısnımansur Rüşdiyesi kayıtlarında rastladık- köylerden gelen sadece 2 öğrenci olduğu, geri kalan hepsinin Hısnımansur merkezinden okula geldiği anlaşılmaktadır ${ }^{45}$.

Hısnımansur Rüşdiyesi eğitim öğretime başladığından itibaren her yıla ait hangi derslerin okutulduğu ile ilgili bir belgeye rastlanmad. Ancak II. Meşrutiyet Dönemi'ne ait bir belge bu konu hakkında fikir vermektedir. Buna göre 1912-1913 ders yılında okutulan dersler, Kur'an-1 Kerim, ulum-1 diniye, Arapça, Farsça, tarih, hesab, hendese, coğrafya, sahv-1 Osmani, ma'lumat-1 medeniye ve ahlak, malumat- shhıye ve fenniye, kıraat, resim, imla, hüsn-i hat ve Fransızca'dır ${ }^{46}$.

Muhtemeldir ki okul, 6 Ekim 1913 tarihli Tedrisât-1 İbtidâiye Kânun-1 Muvakkat düzenlemesi gereği öğrenim süresi 6 yıla çıkarılan ibtidaiye bünyesine alınarak bağımsız okul olma vasfinı yitirmiş̧ir. ${ }^{47}$

\section{Besni Rüşdiye Mektebi}

Bölge halkının, eğitim ve öğretime önem vermesiyle bir okulun kurulup yaşatılmasının nasıl kolaylaştığına en güzel örneklerden birisi Besni Rüşdiyesi'dir. Zira rüşdiye binasının, tüm masrafı Besnili hayırsever Halil Ağazade Muhammed Ağa tarafından üstlenilmiştir. Muhammed Ağa, Kurşunlu Camii'nin sol tarafında, kemer üzerine bir büyük salon ve sekiz odadan oluşan okul binası ve okul binasına ek olarak okula vakfedilmek üzere 7 dükkân, 5 lüleli bir çeşme ve ona bitişik bir gasilhane inşa ettireceğini kaymakamlığa bildirmiştir. Meclis heyeti, ulema ve ahalinin ileri gelenlerinin huzurunda keşif yapılarak inşaata başlanmıştır ${ }^{48}$. Çalışmaların sonucunda, tamamı Muhammed Ağa tarafından karşılanan toplam 25.300 kuruş masrafla beş kemer üzerine iki katlı üstü okul, alt katı ise yedi dükkândan oluşan bir bina ve ilave olarak beş lüleli kâgir bir çeşme ile gasilhane inşaatı tamamlanmıştır. Dükkânlar, icarları mektebin tamir ve bakımı için harcanmak kaydıyla faaliyete geçirilmiştir. Böylelikle okul, 1870 yıllında eğitim öğretime başlamıştır. Bu arada rüşdiye müfredatı için hazırlanan kitap ve risalelerin ivedilikle gönderilmesi için de hükümet nezdinde gerekli girişimlerde bulunulmuştur ${ }^{49}$.

43 İbtidai mektebinin I. Dünya Savaşı'ndan biraz önce açıldığı ile ilgili bkz. BOA. MF. HTF., 4/61, (25 Ra. 1335/19 Ocak 1917).

$44 \quad$ Bkz. dip. 29.

45 BOA. MF. İBT., 381/21, (16 B. 1330/1 Temmuz 1912); BOA. MF. İBT., 452/48, (12 L. 1331/14 Eylül 1913).

46 BOA. MF. İBT., 452/48, (12 L. 1331/14 Eylül 1913).

47 Cemil Öztürk, Rüşdiye, İslam Ansiklopedisi, C.35, TDV, İstanbul, 2008, s.302.

4819 Mayıs 1870 tarihli Diyarbekir Gazetesi'nden aktaran, Atalay, agm, s. 169; Yerel yöneticilerin ve şehrin ileri gelenlerinin rüşdiye yapımını hızlandırmasına en güzel misallerden biri de Besni’nin de b dönemde bağlı buşunduğu Malatya Sancağı merkezinde açılan rüşdiye mektebidir. Burada eşraf ve ahalinin dayanışması ile rüşdiye mektebinin masraflarını karşılamak için dükkânlar kurulmuş, bu dükkânların geliri ile rüşdiye mektebinin masrafları ile muallim maaşları karşılanmıştır; Nalcı ve Gün, agm, s. 109-110.

4911 Kasım 1870 tarihli Diyarbekir Gazetesi'nden aktaran, Atalay, agm, s. 169-170; Atalay, bu gazeteye dayandırarak okulun 50 öğrenciyle eğitim öğretime başladığını dercetmiş; ancak aşağıda görüleceği 
Kurşunlu Cami civarında ${ }^{50}$ yapılan okulun resmî açılışı ise 1871 'de yapılmışıtı ${ }^{51}$. Salname kayıtlarından, okulun açılışı ile birlikte muallim olarak Ahmed Hamdi Efendi'nin göreve başladığı ve bu görevde uzun bir süre kaldığı anlaşılmaktadır ${ }^{52}$. Okulun ihtiyaçları da peyderpey giderilmeye çalışılmıştır. 1873 'te, eğitimin yeni materyallerinden Avrupa, Amerika ve Afrika kıtası haritaları ile birlikte 25 adet coğrafya risalesi nezaret tarafindan okula gönderilmiştir ${ }^{53}$.

Ahmed Hamdi Efendi'den sonra muallim-i sani olan İbrahim Efendi, hakkındaki olumlu ve olumsuz iddialarla bürokratik yazışmalara konu olmuştur. 1887 yılında Malatya Mutasarrıfı Ali Rıza ve diğer azalar tarafından Maarif-i Umumiye Nezareti'ne bir dilekçe yazılarak muallim İbrahim Efendi'nin ödüllendirilmesi istenmiştir. Buna gerekçe olarak da, yörenin müderrislerinden olan İbrahim Efendi'nin adeta tatil havasında olan rüşdiye mektebini gayreti ve çabasılyla sslah etmesini göstermişler, öğrencilerin kendisinden çokça istifade ettiğini iddia ederek bir taşra müderrislik rüûsu* tevcih edilmesini talep etmişlerdir. Mekatib-i Rüşdiye İdaresine gelen bu taltif talebi olumlu karşılanmıştır ${ }^{54}$. Diğer taraftan aynı yıl yazılan Hafız Mehmed imzalı bir başka dilekçede ise İbrahim Efendi ile ilgili çok farklı şikâyetler mevzu bahistir. Buna göre İbrahim Efendi, hüsn-i hat, rika, vs. hiçbir yazı çeşidi bilmemektedir. Bu nedenle, yazı öğrenmek için toplanan öğrencilerin vakitleri boşa gitmekte, eğitimden nasipsiz kalmaktadırlar. "Devlet-i Aliyyemizin şu asar-1 hayriyye de niyeti halisane ile teb'ay-1 ahali-i etfallerinin" kurtuluşu için açtığ rüşdiye mektebi, bu muallim sebebiyle zayi olmakta, hazineden verilen maaş "itlaf" olmaktadır. Zaten İbrahim Efendi'nin göreve ilk başlatılması da birilerinin himayesi ile olmuştur. Böyle devam

üzere salnamelerdeki öğrenci sayısı ile karşılaştırıldığında bu ifadenin doğru olma olasılığı düşüktür. Bunun yanında 1873 'te nezaret tarafından gönderilen coğrafya risalelerinin sayısı da “25 adet”tir; bkz. BOA. MF. MKT. 10/120 (8 R. 1290/5 Haziran 1873); Okulun, kısa sürede bu kadar öğrenci kaybettiğine dair bir delil olmadığına göre gazete haberinde bir yanlışlık olmalıdır.

$50 \quad$ SVM, H. 1312, Nüfus Nezareti Kısm1, s. 19.

51 Maarif Ístatistiki (1310-1311), s. 40.

52 SVD, H. 1288, s. 126; SDA, H. 1294, s. 537; Atalay’ın vilayet gazetesinden yaptığı alıntıda okulun yöre ulemasından İbrahim Efendi'nin muallim-i saniliğiyle başladığı ifade edilmiştir. Buna göre, Ahmed Hamdi Efendi’nin okuldaki görevine başlamasına kadar İbrahim Efendi okulu idare etmiş olmalıdır; bkz. Atalay, agm, s. 169-170.

53 BOA. MF. MKT., 10/120 (8 R. 1290/5 Haziran 1873); Aslında, Osmanlı Devleti uzun süre kıtalı haritalara mesafeli yaklaşmıştır. Ancak coğrafya biliminin gelişmesi ile kıta haritaları okullardaki yerini almıştır. Fotoğraf ve arşiv kaynaklarında, temelde eğitime yönelik ilk Osmanlı haritalarının yeryüzündeki toprakları dünyayı iki kıtaya bölerek tasvir ettiklerini ve her bir kıtayı ayrı haritalara yerleştirdikleri görülmektedir. Toprakları idari amaçlar için kıta esasına göre sınıflandırmak gibi güçlü Osmanlı egemenliği olduğu halde, dünyayı görsel biçimde ayrı kıtalara ayırmak egemenlik alanı üç kıtaya yayılan bir imparatorluk için anlamsızdı. Kıta esasına göre bölmek imparatorluğun topraklarını fiilen küçültüyordu. Daha da ötesi, Osmanlı topraklarının tamamının üç kıtanın sınırlarında bulunmasından dolayı bunların üzerine teker teker odaklanmak Osmanlı topraklarının haritaların köşelerine sıkıştırılmasına neden oluyordu. Haritaların sınırlandırılma biçimleri çoğunlukla Osmanlı egemenlik sahasının çerçeve içinde kalmasını sağlayacak komşu bir kıtanın da harita üzerinde görülmesine izin verse de, dikkat çeksin diye renklendirilen bir haritaya bakan kişinin Osmanlı topraklarıyla ilgili bütünlük duygusunu geliştirmesini hemen hemen imkânsız kılıyordu; Benjamin C. Fortna, Mekteb-i Hümayun, İletişim Yayınları, İstanbul, 2005, s. 221.

* Rüus: Medrese öğrenimini ve stajyerlik görevini tamamladıktan sonra girdikleri imtihanda başarılı olanlara verilen berat ve müderrislik payesi. Daha ayrıntılı bilgi için bkz. Mehmet Zeki Pakalın, Osmanlı Tarih Deyimleri ve Terimleri Sözlüğü, C. 3, MEB, İstanbul, 1983, s. 72. 
ederse iş, Allah korusun, okulun lağvedilmesine kadar gidecek, bunun da hesabı ruz-1 mahşerde görülecektir. Bu sebepten, hem ahalinin çocuklarının vakti hem de hazineden aktarılan para daha fazla zayi olmaması için, gelecek yıl istikamet sahibi ve "hacib-i maarif” bir muallim-i sani tayin edilmelidir. Kendisinin kimseye karşı bir garazı olmadığını ve iftira atmak niyetinde olmadığını dile getiren Hafız Mehmed, beyanlarının hepsinin doğru olduğunu savunmuştur ${ }^{55}$.

Maarif-i Umumiye Nezareti de bu mektubu dikkate alarak yazı çeşitlerini bilmediği ve devamsızlığı gerekçesiyle İbrahim Efendi'nin yerine "erbab-1 iktidardan birinin usul-i vechiyle" seçilmesini Mamuratülaziz vilayetine bildirmiş ${ }^{56}$, Mamuratülaziz vilayeti de adem-i iktidarsızlığ 1 ve devamsızlığını gerekçe göstererek; İbrahim Efendi'nin görevine son vermiştir. Yerine Darülmuallimin diplomasına sahip 1865 Malatya doğumlu Cafer Abdalzade Hüseyin Efendi, 4 Mart 1888 (21 Şubat 1303) tarihinde göreve başlatılmıştır. Ancak, Mekatib-i Rüşdiye İdaresi buna itiraz ederek Hüseyin Efendi'nin diplomasının ibtidai mektepleri muallimliği için geçerli olduğunu ve bu sebepten rüşdiye mektebi muallimliği için yapılan imtihana tabi tutulmasını istemiştir ${ }^{57}$. Bunun üzerine, Malatya Rüşdiye Mektebi Muallim-i evveli ve Diyarbekir mülga Maarif Müfettişi Osman Efendi'nin hazır olduğu bir ortamda imtihan edilen Hüseyin Efendi, rüşdiye muallimi olmaya hak kazanarak 23 Ekim 1888'de görevine başlatılmıştır ${ }^{58}$. İlk kurulduğu yıllarda Ahmed Hamdi Efendi'nin idaresinde 20 civarlarında talebesi olan, sonra Hakkı Efendi zamanındaki 2 y1l içinde 70'e kadar çıkan talebe sayısı 1887'de göreve gelen Hüseyin Efendi idaresinde de 40'l1 rakamlarda devam etmiştir ${ }^{59}$.

Ancak, Hısnımansur Rüşdiye Mektebi muallim-i sanisinin vefatına müteakip Hüseyin Efendi, Besni Rüşdiyesi’nden Hısnımansur Rüşdiyesi’ne tayin istemiştir. Buna gerekçe olarak da Besni’nin havasına uyum sağlayamadığını ve maaşının yetersizliğini dile getirmiştir. Silsile itibariyle de bu görevin kendisine verilmesi gerektiğini ifade eden Hüseyin Efendi’ye, Rüşdiye Mektepleri İdaresi, Hısnımansur'a başka biri tayin olduğundan bu isteğin gerçekleştirilemeyeceği cevabını vermiştir. ${ }^{60}$

55 BOA. MF. MKT. 93/135, (8 Ş. 1304/2 Mayıs 1887). Aynı y1la ait iki farklı belgeden İbrahim Efendi ile ilgili iki farklı bilginin gelmesi, durumu çetrefilli bir hale getirmesi yanında bazı gerçeklerin ortaya çıkmasını sağlamaktadır. Yöre ahalisinden Hafız Mehmed'in şikâyet dilekçesini doğru kabul ettiğimizde, bir önceki belgede İbrahim Efendi’ye verilen ödülün mahiyeti de az çok anlaşılmaktadır. Zira muallimliğe getirilmesi de birilerinin yardımıyla olan İbrahim Efendi’ye yine aynı birileri tarafından ödül verilmesinin istenmesi mümkündür. Bu durum bize göstermektedir ki, birçok dönemde olduğu gibi, bahsi geçen zaman diliminde de hatır- gönül ve tanıdık ilişkileri devreye girmiş, liyakat ikinci plana atılmıştır.

$56 a g b$.

57 BOA. MF. MKT., 98/125, (18 N. 1305/ 29 May1s 1888); Maarif belgesinin ekinde Hüseyin Efendi'nin Darulmualliminde aldığ 1 dersler ve notları yer almaktadır. Buna göre, Hüseyin Efendi şu dersleri ve puanları almıştır: Arapça: 8, Farsça: 9, Kavaid-i Türkçe: 9, Hesab: 9, Coğrafya: 8, Tarih: 10, Tecvid (Tatbikatıyla beraber): 10, Usül-1 Cedide-i Elifba: 10, Hutut-1 Mütenevvia: 10; Toplam puan: 83; BOA. MF. MKT., 98/125, (18 N. 1305/ 29 Mayıs 1888); Görüldüğü üzere rüşdiyelerde okutulan birçok ders bu listede yer almamaktadır; bkz. Ek 2.

58 BOA. MF. İBT., 22/40, (19 M. 1306/25 Eylül 1888); BOA. MF. İBT., 22/96, (27 R. 1306/31 Aralık 1888); BOA. MF. MKT., 103/87, (17 S. 1306/23 Ekim 1888).

59 Bkz. Tablo 3; Mekatib-i İbtidayece istenen bir çizelgede ise Besni Rüşdiyesi’nin 1883 yılında 50, 1884 yılında 70, 1885 yılında ise 45 öğrencisi bulunmaktadır. 1885 yılında okulun mezun sayısı ise 10'dur; BOA. MF. İBT., 20/19, (6 R. 1303/12 Ocak 1886).

60 BOA. MF. MKT., 113/91, (06-03-1306/10.11.1888). Belgenin tarihi Başbakanlık Devlet Arşivleri’nin kataloglarında bu şekilde verilmiş, ancak yazışmalar daha sonraki tarihlerde -R. 10-19 Teşrin-i Evvel 
Dolayısıyla da Hüseyin Efendi, bu göreve devam etmiştir. Ancak, bu belge Hüseyin Efendi'nin Besni' de pek mutlu olmadığını ve geçim sıkıntısı yaşadığını yansıtması bakımından kayda değerdir.

1890 yılında, yörenin rüşdiye okulları yakın takibe alınmış; 1slahları mümkün olanların 1slahı, bir türlü talebe ve eğitimleri yönüyle istenen kıvama gelemeyenlerin ise kapatılması düşünülmüştür. Besni Rüşdiyesi de, ıslahına karar verilen rüşdiyelerdendir ${ }^{61}$. Bunun akabinde okula bir rika mualliminin istenmesi ${ }^{62}$, sslah çalışmaları kapsamında düşünülmüş olmalıdır.

Bu 1slah düşüncesinden sonra rüşdiye mektebine baktığımızda, okul öğrenci sayısının geçen 10 seneye nazaran yüksek bir oranda devam etmekte olduğunu görmekteyiz. Alkan'1n verdiği rakamları esas alırsak 1883 'te 20 olan öğrenci sayıs1 ${ }^{63}, 1893$ yılında mezun olanlar çıktıktan sonra 35 olmuştur. 1894-95 yılında 10 yeni öğrenci kaydolmuş, 5 öğrenci ise bu yıl içinde okuldan ayrılmıştır. Yapılan sınav sonucu 4 öğrenci diploma almaya hak kazanmış, böylelikle, 1895-96 sezonuna 36 öğrenci devretmiştir ${ }^{64}$. Besni Rüşdiyesi’nin öğrenim süresi bu yıllarda hâlâ 4 yıl olarak devam etmiştir ${ }^{65}$. Dersaadet'te alınan rüşdiyelerin 3 yıla indirilmesi ile ilgili 1892 yılına ait karar ${ }^{66}$ ancak 1901 'den sonra uygulanmaya başlayacaktır ${ }^{67}$. Bu durum aslında merkezin aldığı kararların yerelde vaziyete göre yorumlanarak uygulandığını göstermektedir.

$\mathrm{Bu}$ arada, 80 kuruş maaş tahsisi yapılan rika muallimliğine okulun muallim-i sanisi Hüseyin Efendi görevlendirilmiştir. Yazı numuneleri nezaret tarafından beğenilen Hüseyin Efendi, 1893 yılında, ilave memurluk şeklinde rika muallimliğini de yapmaya başlamıştır ${ }^{68}$. Böylelikle yeni bir muallim tayini yapılmamış, Hüseyin Efendi’nin geçim sıkıntıları bir nebze hafifletilmeye çalışılmıştır. Hüseyin Efendi, muallim-i sanilik görevine vefat ettiği tarih olan 25 Eylül 1897 yılına kadar devam etmiştir. Vefat ettiğinde henüz 45 yaşındadır. Hüseyin Efendi'nin eşine göre, kocası çok fazla derse girdiği için hastalanmış ve buna bağlı olarak da vefat etmiştir ${ }^{69}$.

Muallim-i sanilik ile beraber rika muallimliği yapmakta olan Hüseyin Efendi’nin vefatından sonra yerine iki muallim atanmıştır. Bunlardan birisi muallimi-i evvel olarak Yunus Efendi, diğeri de hüsn-i hat muallimi olarak Mehmed Efendi'dir ${ }^{70}$. Muallimliğe 1876 yılında Kilis'te başlayan Yunus Efendi, daha sonra sırasıyla Kilis, Mut, Zor, Çermik ve Diyarbekir rüşdiyelerinde görev

1305/18-27 Ekim 1889- yapılmıştır.

61 BOA. MF. MKT., 105/90, (26 Ca. 1306/28 Ocak 1889); BOA. MF. MKT., 117/56, (18 Ș. 1307/30 Mart 1890).

62 BOA. MF. MKT., 153/150, (20 R. 1310/10-11-1892).

63 Mehmet Ö. Alkan, Tanzimat'tan Cumhuriyet'e Modernleşme Sürecinde Ĕgitim İstatistikleri (1839-1924), DíE, Ankara, 2011, s. 45.

64 Maarif Ístatistiki (1310-1311), age, s. 40.

65 Besni Rüşdiyesi'nin öğretim süresinin 4 y1l olduğuna dair bkz.; BOA. MF. İBT., 37/68, (17 Z. 1311/21 Haziran 1894); BOA. MF. İBT., 43/85, (16 N. 1312/13 Mart 1895); BOA. MF. İBT., 45/55, (29 Z. 1312/23 Haziran 1895).

66 Bkz. Kodaman, age, s. 112.

67 Besni Rüşdiyesi’nin öğretim süresinin 3 yıla düşürüldüğüne dair bkz.; BOA. MF. İBT., 109/44, (9 L. 1319/19 Ocak 1902); BOA. MF. İBT., 139/11, (16 B. 1321/8 Ekim1903).

68 BOA. MF. MKT., 180/66, (29 S. 1311/10 Eylül 1893).

69 BOA. MF. MKT. 443/33, (29 Z. 1316/10 Nisan 1899).

70 SNMU, H. 1316, s. 1171. 
yapmış tecrübeli bir eğitimcidir ${ }^{71}$. Böyle bir özgeçmişe sahip bir muallimin görevlendirilmesi aynı zamanda Besni'nin Maarif Nezareti'nce önemsendiğini göstermektedir. Yunus Efendi'nin görevinin ilk yıllarında öğrenci sayısında bir düşüş yaşansa da sonra toparlanarak artmıştır ${ }^{72} .30$ Haziran 1898 tarihinde Besni'deki muallim-i evvellik görevine başlayan Yunus Efendi de vefat ettiği 16 Mayıs 1904 tarihine kadar, yaklaşık 6 yıl, bu görevde kalmıştır ${ }^{73}$.

Yunus Efendi’nin vefatıyla birlikte, Besni Rüşdiyesi muallimliği için iki talip çıkmıştır. Bunlardan birisi merhum Muallim-i Evvel Yunus Efendi’nin oğlu İsmail Niyazi'dir. İsmail Niyazi, Halep İdadisi'ni bitirdikten sonra Dersaadet'e giderek Küçük Ayasofya Camii yanındaki Darülhadis medresesinden ders almış, bunun akabinde Hukuk-1 Şahane'yi kazanmış ve buranın birinci yılını okumaktadır. Diğeri ise Darülmuallimin-i Rüşdiye mezunu Hacı Mehmed Efendi' dir. Yunus Efendi'nin oğlu olan İsmail Niyazi, yazdığı dilekçesinde kendisinin Hukuk-1 Şahane'yi bırakıp muallimlik istemek zorunda kalmasını, babasının ani vefatıla ailesinin acınacak durumda kalmasına bağlayarak, kendisine bu görevin verilmesinin ailesinin acılarına bir nebze merhem olacağını ifade etmiştir. İki talip arasından Mekatib-i Rüşdiye İdaresi, Darülmuallimin-i Rüşdiye'den mezun olduğu için Hacı Mehmed Efendi'yi bu göreve atamıştır ${ }^{74}$. Bu atama, başka bir açıdan, Osmanlı medreselerinde görülen "beşik ulemalığı"nın modern eğitim kurumlarına bulaşmadığını göstermektedir.

Abdülhamid Devri'nin sonuna gelirken ise 37 olan öğrenci sayısı ile okulun başında Hacı Mehmed Vasıf Efendi yer almaktadır ${ }^{75}$. Salname kayıtlarına göre yıllık ortalama öğrenci sayısı $32^{76}$ olan Besni Rüşdiyesi’nde öğrenci sayıları 20 ile 70 arasında değişmiştir. Finans olarak sağlam kaynaklara dayandırıldığından Hısnımansur ve Kâhta rüşdiyelerine nazaran daha az mali sorun yaşamıştır. Ancak, bu durum mali açıdan hiç sorun yaşanmadığı anlamına gelmemektedir.

Besni Rüşdiyesi ile ilgili karşımıza çıkan mali meseleler, o dönem maarifinin ve dahi muallimlerin yaşadığı zorlukları göz önüne sermektedir. Buna karşın kazanın en büyük şansı, bir hayır sahibinin rüşdiye yapım ve masraflarını üstlenmiş olmasıdır. Diğer türlü, daha büyük mali sorunların yaşanması kaçınılmaz olurdu. Zira $1885^{\prime}$ 'lere gelindiğinde, şehirde hâlâ maarif sandığı oluşturulamamıştı. 1885 yılında Besni'de yanlış giden işlerin merkezden haber alınması üzerine maliye müfettişleri görevlendirilmişti. Yapılan tahkikat sonucunda anlaşıldı ki, maarif ve menafi sandıklarına mahsus yüzde altı müsakkafat vergisinden hiçbir akçe tahsil edilemediği gibi, menafi

71 BOA. ŞD 1041/72, (17 N. 1323/14 Kasım 1905).

72 Bkz. Tablo 3.

73 BOA. ŞD, 1041/72, (17 N. 1323/14 Kasım 1905).

74 BOA. MF. MKT., 792/62, (15 Ca. 1322/29 Temmuz 1904); İsmail Niyazi’nin dilekçesi “kul”" kavramından "vatandaş" bilincine geçilemediğine dair işaretler barındırmaktadır. İsmail Niyazi ailesine verilecek tekaüt maaşının ailenin geçimine yetmeyeceğini belirttikten sonra şöyle devem etmiştir: “... hem çakerlerinin ve hem de hem de aile-i keder-dide kullarının şimdiden sonra aç ve bi-ilaç kalacağı bi-iştibah (şüpheden uzak) olmağla lütfen ve merhum pederimin yirmi yedi sene bi'l-infisal meslek-i maarifde olan hissi hizmetine mükafaten ve yetim ve bikes kalan çoluk ve çocuğunun şu def'a-yı me'lume ve müessifeden münbais hal-i pür-melallerine merhameten bendelerinin pederimden münhal olan mekteb-i mezkur muallim-i evvelliğine ta'yin buyurulmaklığım ile cümlemizin arzusunun ihya kılınmasını müsellim-i in'am olan merhamet ve inayet-i celile-i cenab-1 nezaretpenahilerinden kemal-i ibtihal ve tazarru' ile istirham eylerim..."; $a g b$.

75 SVM, H. 1325, s. 96.

76 Uğur Ünal, II. Meşrutiyet Öncesi Osmanlı Rüşdiyeleri (1897-1907), TTK, Ankara, 2015, s. 173. 
ve maarife ait aşarın 1/7 ve 1/4'ünden tahakkuk eden doksan bir bin dokuz yüz yetmiş beş (91.975) kuruş tahsilattan bir kısmı merkez livaya gönderilmiş, diğer bir kısmı ise mahalli ihtiyaçlar için kullanılmıştı. Maarif Nezareti, bu durumu haber alınca, yanlış olan bu uygulamadan hemen vazgeçilmesini isteyerek 1885 yılına ait maarif hisse-i ianesinden ne kadar tahsilat yapıldığını, kullanılmayan kısmın ne kadar olduğunu ve Dersaadet için gönderilmesi gereken miktardan ne kadarının gönderildiği bilgilerini vilayetten istemiş̧ti. Bunun yanında maarif hissesine ait kısımdan kullanılan meblağın diğer gelirlerden alınarak yerine konulması gerektiği belirtilmişti ${ }^{77}$. Aslında, o yıllarda, maarife ait gelirin mahalli bazı ihtiyaçlar için kullanılması sadece Besni'de olan bir şey değildi; genel bir problemdi ${ }^{78}$.

Vergilerin düzenli toplanamaması ve yukarıda görüldüğü gibi bir kısmının da yükseköğrenim ve Dersaadet'teki okullar için kullanılmak üzere merkeze gönderilmesi beraberinde mali problemleri getiriyordu. 1889 yılında Muallim-i Sani Hüseyin Efendi, ailesi kalabalık olduğundan aldığı maaşın geçimini idareye yetmediği gerekçesiyle Besni'den tayinini istemişti ${ }^{79}$. Tayin istediği Hısnımansur Rüşdiyesi muallimliği doldurulmuş olduğundan Hüseyin Efendi'nin sorunu hemen çözülememiş, 1893 'te Besni Rüşdiyesi'nde rika muallimliği kadrosu açıldığında 80 kuruş ilave maaşla kendi okulunda göreve devam etmiştir ${ }^{80}$. Böylelikle, muallim-i sani olarak aylık 250 kuruş maaş almakta olan Hüseyin Efendi ${ }^{81}$, bundan sonra kesintiler olmadan toplamda 330 kuruş maaş alacaktır.

Yıllar ilerlediğinde Besni Rüşdiyesi muallimlerinin geçim sıkıntısı yaşamaya devam ettiğgi anlaşılmaktadır. Okulun ilk muallim-i evveli olan Yunus Efendi'nin Maarif Nezareti'ne yazdığı dilekçe dönemin fotoğrafını bize yansıtması bakımından oldukça önemlidir. 1904 yılında yazılan bu dilekçeye göre, muallim ve hademenin alacağı maaş yöre halkından toplanan maarif hisse-i ianesinde olması gerekirken mal sandıklarına devredilmiştir. Böyle olunca da maliyenin sıkıntılı hali ile memurların kötü idareleri ve usul bilmemeleri birleşince Kurban Bayramı'nda bile maaş alamamışlardır. Maaş alamadıkları ay toplamı ise "beş" olmuştur. Bunun neticesinden ailesi perişan duruma düştüğü gibi, Dersaadet'te okuttuğu oğlu da acınacak derecede bir zaruretin içinde kalmıştır. Bu kadar zor duruma düştüğünden nezarete yazmaya mecbur kaldığını söyleyen Yunus Efendi, emsalleri gibi kendilerine de maarif hisse-i ianesinden maaşlarının verilmesini istemiştir.

Yunus Efendi'nin yazdığı bu dilekçe maarif nezaretini, vilayet muhasebe memurlarını soruşturmaya itmiş̧ir. Zira mali durumun en sikıntılı olduğu yerlerde bile, bayramlar öncesinde muallimlere maaş verilmektedir. Ancak anlaşılan, Besni'de rüşdiye personeli beş aydır maaş alamamıştır. Nezaret, Yunus Efendi'nin dilekçesine karşılık olarak Mamuratülaziz vilayetine bir yazı yazarak, maarif memurları maaşlarının ziraat bank şubelerinden verilmeyip, hepsinin mal sandığına havale edilmesinin sebebini sormuştur. Hâlbuki nezaret tarafından vilayetlere gönderilen

77 BOA. MF. MKT., 88/44, (26 M. 1303/4 Kasım 1885); BOA. MF. MKT., 88/118, (24 S. 1303/2 Aralık 1885); Maarif hisse-i ianesi, gerçekte öşür üzerine eklenen 1/7 oranındaki bir vergi olup, toplam miktarın 1/3’ü eğitime ayrılmıştı. Toplam öşürün \%5.3'ü maârif hisse-i ianesi olarak değerlendirilmişti. Meblağın 2/3'ü de diğer kamu işlerinin tahsisatıydı. Kamu hizmetlerine ayrılan kısım, yani menafi hissesi, toplam öşürün \%10.6'sıyd1; Arzu M. Nurdoğan, Osmanlı Modernleşme Sürecinde İlköğretim (1869-1922), Yayımlanmış Doktora Tezi, Marmara Üniversitesi, Sosyal Bilimler Enstitüsü, İstanbul, 2005, s. 464.

78 Selçuk Akşin Somel, Osmanlı'da Eğitimin Modernleşmesi (1839-1908), İletişim Yayınları, İstanbul, 2015, s. 189-190.

79 BOA. MF. MKT., 113/91, (06-03-1306/10.11.1888).

80 BOA. MF. MKT., 180/66, (29 S. 1311/10 Eylül 1893).

81 BOA. MF. MKT., 443/33, (25 S. 1317/3 Temmuz 1899). 
tebligatta maaşlarının bir kısmının mal sandığından bir kısmının ise Ziraat Bankası şubelerinden ödenmesi istenmişti. Yapılan incelemeler sonucunda, vilayet bütçesinin açık vermiş olduğu ve bundan dolayı böyle bir uygulamaya gidildiği tespit edilmiştir ${ }^{82}$.

Muallimlerin ve diğer maarif memurlarının geçim sıkıntısı yaşamasında, Osmanlı Devleti maliyesinin genel sıkıntılarının yanında vilayet idarecilerinin de payı büyüktür. Zira Yunus Efendi'nin, Maarif Nezareti'ne yazdığı dilekçeden bir yıl önce Mamuratülaziz Maarif Müdürü, yaklaşan tehlikeye dikkat çekmiş; kazada maarif için toplanan paraların livada harcandığını ve maarif sandığına aktarılmadığını, bu hâl devam ettiği sürece maarif memurlarına maaş verilmesinin uzun süre sekteye uğrayacağını ifade etmişti ${ }^{83}$. Yukarıda görüldüğü üzere, maarif müdürünün bu ikazını dikkate alan pek olmamıştır. Bu sıkıntıların akabinde bazı düzenlemeler yapılmış, bir de tenkisata gidilmiştir. Örneğin, Yunus Efendi'ye muallim olarak 600 kuruş maaş belirlenmişken, kendisinin vefatı ile yerine geçen Hacı Mehmed Efendi'ye 500 kuruş maaş tahsis edilmişti ${ }^{84}$. Yani, fedakârlık yine öğretmenlere düşmüştü.

Yaklaşık 24 yılını muallimlik yaparak geçirmiş olan Yunus Efendi’nin yıllar içinde aldığı maaşlar, bize çok önemli veriler sunmaktadır. Zira Yunus Efendi'nin göreve başladığı 1879 yılında aldığı maaş ile vefat ettiği 1904 arasında aldığı maaş aynıdır. Yunus Efendi'nin çalıştığ yerler ve maaşlarının yıllar içindeki seyrine baktığımızda bu durum daha net olarak ortaya çıkacaktır:

Tablo 3. Besni Rüşdiyesi Muallimi Yunus Efendi’nin Görev Yerleri ve Aldığı Maaşlar ${ }^{85}$

\begin{tabular}{|l|c|c|}
\hline Görev yeri & Çalıştığı yıllar & $\begin{array}{c}\text { Aldığı aylık maaş } \\
\text { (kr) }\end{array}$ \\
\hline Kilis Rüşdiyesi & $1879-1880$ & 600 \\
\hline Kilis Rüşdiyesi & $1880-1893$ & 480 \\
\hline Mut Rüşdiyesi & $1893-1894$ & 500 \\
\hline Çermik Rüşdiyesi & $1896-1897$ & 500 \\
\hline Diyarbekir Rüşdiyesi & $1897-1898$ & 540 \\
\hline Besni Rüşdiyesi & $1898-1904$ & 600 \\
\hline
\end{tabular}

Maaşların azlığı ve çokluğunun coğrafi önem ve öğrenci sayısı ile de doğru orantılı olduğu tezi ${ }^{86}$ Yunus Efendi örneğini ele aldığımızda yara almaktadır. Zira coğrafi önem itibariyle birbirlerine yakın olsalar da vilayet merkezi olması hasebiyle en hassas öneme sahip olan Diyarbekir Merkez Rüşdiyesi olmalıdır. Ama baktığımızda, Yunus Efendi’ye burada, Kilis, Zor ve Besni rüşdiyelerinden daha düşük maaş verilmiştir. Yine öğrenci sayısına baktığımızda da Diyarbekir öğrenci sayısı daha yüksektir ${ }^{87}$ ve burada maaşın daha yüksek olması beklenir. Ama öyle olmamıştır. Durum göstermektedir ki, muallim maaşlarını etkileyen bahsi geçen öğelerden

\footnotetext{
82 BOA. MF. MKT., 778/54, (23 S. 1322/8 May1s 1904).

83 BOA. MF. MKT., 734/29, (13 Ca. 1321/8 Ağustos 1903).

84 BOA. MF. MKT., 792/62, (15 Ca. 1322/29 Temmuz 1904).

85 BOA. ŞD 1041/72, (17 N. 1323/14 Kasım 1905); Bu yıllar içinde gelişen enflasyon ve tüketici fiyat endeksleri için bkz. Şevket Pamuk, "İstanbul ve Diğer Osmanlı Kentlerinde Fiyatlar”, XIII. Türk Tarih Kongresi, (II. Cilt), 04-08 Ekim 1999, Ankara, 101-128.

$86 \quad$ Nurdoğan, agt, s. 518.

87 Bkz. Hatip Yıldız, Diyarbekir Vilayeti’nde Eğitim (1870-1920), Atatürk Üniversitesi, Sosyal Bilimler Enstitüsü, Yayımlanmış Doktora Tezi, Erzurum, 2007, s. 132-133.
} 
başka birçok unsur vardır: Merkez maliyenin durumu, yöre halkının eğitime katkısı, okulun sağlam finans kaynaklarına dayanıp dayanmayışı, muallimin ailesinin durumu ve kalabalıklı̆̆ bunlardan en önemlileridir. Ayrıca, 1869 Maarif Nizamnamesi'nde muallim-i evvel için belirlenen aylık 800 kuruş maaşın Yunus Efendi'ye, sadece 2 yıl, Zor Rüşdiyesi'nde verildiği daha sonra verilemediği -zaten mali durum kötüye doğru gidince nezaret de bu planlamadan vazgeçmişti ${ }^{88}{ }_{\text {- }}$ ortaya çıkmaktadır.

Osmanlı Devleti, incelediğimiz dönem içinde, modern devlet olmanın gereklerini yerine getirmeye çalışmaktaydı. Özellikle, emeklilik hakkıvevefateden memurun eşine ve çocuklarına maaş bağlanması bunların başında gelmekteydi ${ }^{89}$. Muallimler görevde iken maaşlarından emeklilikleri için "tekaüd sandığı"na para aktarılıyordu. Örneğin, muallim-i sani Hüseyin Efendi 1888 y1lında göreve başladığında ilk aldığı maaşın yarısı tekaüt sandığına aktarılmıştı ${ }^{90}$. Ancak, Hüseyin Efendi ve Yunus Efendi'nin görevleri başında iken vefatlarını - kayıtlara geçmeyen vefatlar da olabileceği gerçeğiyle- düşündüğümüzde, muallimlerin önemli bir bölümü için emeklilik hayatının hayalden pek de öteye geçemediği anlaşılmaktadır. Bu dönem emekli maaşlarının oldukça düşük olması da muallimleri yaşları ilerlese de çalışmaya zorlayan bir neden olmalıdır ${ }^{91}$.

Muallimlerin vefatından sonra, eş ve çocuklarına "yetim ve dul maaşı" bağlanması ise 10 yıl çalışma şartına bağlanmıştır. Bu durum, Hüseyin Efendi'nin vefatından sonra eşi ve yetim bıraktığı 2, 8 ve 11 yaşlarındaki 3 çocuğu için sıkıntılı bir süreci beraberinde getirmiştir. Zira Hüseyin Efendi'nin çalıştı̆̆ı süre, 9 yıl 7 aydır. Bunun üzerine, Malatya mutasarrıflığı, Malatya'nın İskender Mahallesi'nde sakin olan ailenin araştırılmasını istemiştir. Yapılan tahkikat sonucunda, ailenin perişan durumda olduğu, Hüseyin Efendi' den geriye emlak ve arazi gibi herhangi bir mülk kalmadığı anlaşıldığından aileye yardım etmenin merhametli devletimizin şanına uygun olacağ ifade edilmiştir. Sonuçta, emekli maaşı bağlanması mümkün olmadığından aileye muhtaçlar fonundan bir yoksul aylığı bağlanmasına karar verilmiştir92. 1904'te vefat eden Yunus Efendi'nin ailesine ise "Tekaüd Kararnamesi" gereğince 123 kuruş maaş tahsisi kararı alınmıştı". Yukarıda

88 Somel, age, s. 207.

89 Osmanlı İmparatorluğu’nda 19. yüzyılın son çeyreğinde çalışanların sosyal güvenlikleri konusunda "lütuf ve sadaka" anlayışından "çalışma hakkı" veya "hizmet hakkı" anlayışına geçtiğine dair; bkz. Abdullah Martal, "Osmanlı İmparatorluğu’nda Emeklilik ve Buna İlişkin Düzenlemeler”, XIII. Türk Tarih Kongresi, (III. Cilt-III. K1s1m), 04-08 Ekim 1999, Ankara, 1698.

90 BOA. MF. MKT., 103/87, (17 S. 1306/23 Ekim 1888). Muallimlerin maaşlarından bazı olağanüstü durumlar için de kesintiler yapılmaktaydı. Hüseyin Efendi’ye bahsi geçen ilave memurluk verildiğinde, 80 kuruşluk maaşından \% 10 yangın ianesi kesilmesi istenmişti.

911908 yılında emekli olan Hüseynik Rüşdiyesi muallimi Muharrem Efendi’ye emekli maaşı olarak aylık 83 kuruş bağlanmıştır; BOA. MF. MKT. 1022/50, (10 N. 1325/1 Kasım 1907). Öğretmenlerin çalışırken aldıkları aylık 200-300 kuruş ile rahat geçinemediklerini düşündüğümüzde bu gelir oldukça düşüktür.

92 BOA. BEO, 1348/101065, (23 Ra. 1317/1 Ağustos 1899); BOA. MF. MKT. 443/33, (25 S. 1317/3 Temmuz 1899).

93 BOA. ŞD 1041/72, (17 N. 1323/14 Kasım 1905). Yunus Efendi’nin ailesine maaş bağlanması "Mülkiye-i Mütekaidin ve Ma'zulin Sandıkları Nezareti” tarafından kararlaştırılmıştır. Kararın altında Nazır'ın mührü olduğu gibi, Duyun-1 Umumiye-i Osmaniye Mektebi Emini ve diğer azaların da mühürlü imzaları mevcuttur; 123 kuruş maaş verilmesine nasıl karar verildiğini bilmiyoruz ancak, Yunus Efendi'den 3 yıl sonra vefat eden Çemişgezek Rüşdiye Mektebi muallimi Mustafa Efendi vefat ettikten sonra ailesine maaş olarak bağlanan 150 kuruşun 2 oğlu, 2 kızı ve eş olmak üzere her birisine 30'ar kuruştan hesaplandığ 1 anlaşılmaktadır. Yani, ailenin geriye 5 ferdi kalmış, her ferdine 30 kuruş aylık bağlanmıştır; bkz. BOA. ŞD 1073/77, (6 S. 1326/10 Mart 1908); verilen bu maaş, erkek yetimler için 20 yaşına kadar, kız yetimler 
geçtiği üzere, Yunus Efendi'nin Dersaadet'te okuyan oğlu ise babasından geriye mal ve mülk anlamında hiçbir şey kalmadığını ifade ederek bu para ile geçimlerinin zor olduğunu Maarif Nezareti'ne yazmışıtı" ${ }^{94}$ Aslında, çalıştıkları yıllarda dahi geçim sıkıntısı çeken muallimlerin, kendi imkânlarıyla menkul veya gayrimenkul edinememeleri çok şaşırtıcı bir durum değildir. Bunun yanında, daha yüksek maaş alan muallimlerin şikâyetlerini incelediğimizde bu emekli maaşı ile bir ailenin geçinmesinin pek kolay olmadığı da daha rahat anlaşılacaktır.

Tablo 4. Salnamelere Göre Besni Rüşdiyesi Personel ve Öğrenci Sayısı

\begin{tabular}{|c|c|c|c|c|c|}
\hline Yil & M. evvel & M. sani & Hat M. & Bevvap & Talebe \\
\hline $1871^{26}$ & & $\begin{array}{l}\text { Ahmed Hamdi } \\
\text { Ef. }\end{array}$ & & & \\
\hline $1872^{27}$ & & $\begin{array}{l}\text { Ahmed Hamdi } \\
\text { Ef. }\end{array}$ & & & \\
\hline $1873^{28}$ & & $\begin{array}{l}\text { Ahmed Hamdi } \\
\text { Ef. }\end{array}$ & & & \\
\hline $1874^{29}$ & & $\begin{array}{l}\text { Ahmed Hamdi } \\
\text { Ef. }\end{array}$ & & & \\
\hline $1875^{30}$ & & $\begin{array}{l}\text { Ahmed Hamdi } \\
\text { Ef. }\end{array}$ & & & 20 \\
\hline $1876^{31}$ & & $\begin{array}{l}\text { Ahmed Hamdi } \\
\text { Ef. }\end{array}$ & & Mehmed Ali Ef. & 25 \\
\hline $1877^{32}$ & & $\begin{array}{l}\text { Ahmed Hamdi } \\
\text { Ef. }\end{array}$ & & $\begin{array}{l}\text { Mehmed Said } \\
\text { Ef. }\end{array}$ & 25 \\
\hline $1882^{33}$ & & İbrahim Ef. & & & 20 \\
\hline $1883^{34}$ & & & & & 20 \\
\hline $1884^{35}$ & & Hakkı Ef. & & $\begin{array}{l}\text { Şeyh Mehmed } \\
\text { Ef. }\end{array}$ & 70 \\
\hline $1885^{36}$ & & Hakkı Ef. & & $\begin{array}{l}\text { Şeyh Mehmed } \\
\text { Ef. }\end{array}$ & 70 \\
\hline $1886^{37}$ & & & & & 70 \\
\hline $1887^{38}$ & & & & & 40 \\
\hline $1888^{39}$ & & Hüseyin Ef. & & $\begin{array}{l}\text { Şeyh Mehmed } \\
\text { Ef. }\end{array}$ & 40 \\
\hline $1890^{40}$ & & Hüseyin Ef. & & $\begin{array}{l}\text { Şeyh Mehmed } \\
\text { Ef. }\end{array}$ & 40 \\
\hline $1891^{41}$ & & Hüseyin Ef. & & $\begin{array}{l}\text { Şeyh Mehmed } \\
\text { Ef. }\end{array}$ & 40 \\
\hline $1892^{42}$ & & Hüseyin Ef. & & $\begin{array}{l}\text { Şeyh Mehmed } \\
\text { Ef. }\end{array}$ & 40 \\
\hline $1894^{43}$ & & Hüseyin Ef. & & $\begin{array}{l}\text { Şeyh Mehmed } \\
\text { Ef. }\end{array}$ & 42 \\
\hline $1898^{44}$ & Yunus Ef. & & $\begin{array}{l}\text { Mehmed } \\
\text { Ef. }\end{array}$ & 1 * & 28 \\
\hline
\end{tabular}

ve dullar için ise evlenmelerine kadard1; bkz. Martal, agm, s. 1694.

94 BOA. MF. MKT. 792/62, (15 Ca. 1322/29 Temmuz 1904). 


\begin{tabular}{|l|l|l|l|l|l|}
\hline $1899^{45}$ & Yunus Ef. & & $\begin{array}{l}\text { Mehmed } \\
\text { Ef. }\end{array}$ & 1 & 27 \\
\hline $1900^{46}$ & Yunus Ef. & & $\begin{array}{l}\text { Mehmed } \\
\text { Fuad Ef. }\end{array}$ & 1 & 37 \\
\hline $1901^{47}$ & Yunus Ef. & & $\begin{array}{l}\text { Mehmed } \\
\text { Fuad Ef. }\end{array}$ & 1 & 37 \\
\hline $1903^{48}$ & Yunus Ef. & & Fuad Ef. & 1 & 32 \\
\hline $1907^{49}$ & $\begin{array}{l}\text { Haci Mehmed } \\
\text { Vasif Ef }\end{array}$ & & & & 37 \\
\hline
\end{tabular}

Meşrutiyet yıllarına girdiğimizde Mehmed Vasıf Efendi, muallim-i evvel olarak görevinin başındadır. Ancak okulun öğrenci mevcudunda bir düşüş olmuştur. Nitekim toplam öğrenci sayıs1 1908'de 27 iken5, 1909'da 20'ye ${ }^{96}$ kadar düşmüştür. Yerel maarif idarecileri bu düşüşü okulun tek bir muallimle idare edilmesine bağlamışlardır. 1909 y1lında Vilayet Müdürlüğü'nce hazırlanan raporda bu eksikliğe dikkat çekilerek "Besni kasabasının cesametine göre bir muallim-i sani ihtiyacı derkardır. Bir muallim-i sani ilave edilmedikçe muallim-i evvel ne mertebe gayret gösterse nevakısdan hali kalmaz" ifadesine yer verilmiştir ${ }^{97}$. Ancak bu rapordan sonra 2 y1l geçmiş olmasına rağmen bir atama yapılamamıştır. 1911 yılında teftişe çıkan Vilayet Maarif Müdürü Mehmed Hayri Efendi, bu durumu fark ederek Maarif Nezareti’ne arzuhal yazmış, Besni Rüşdiyesi'ne bir muallim-i sani tahsis edilmesini talep etmiştir. Zira rüşdiye mektebindeki artan öğrenci sayısına göre bir muallim buraya kifayet etmemektedir ${ }^{98}$. Bu defa yazılan arzuhalin ișe yaradığ1 anlaşılmaktadır. Zira 13 Aralık 1911 (30 Teşrinisani 1327)'de Münbiç Rüşdiyesi'nden Zeki Efendi Besni Rüşdiyesi'ne muallim-i sani olarak atanmıştır. Zeki Efendi aylık 300 kuruş alacaktır. Mehmed Vasıf Efendi'nin aldığı maaş ise aylık 500 kuruştur ${ }^{99}$. Ancak, Mehmed Vasıf Efendi 1910 yılından beri Besni şehrinin havasının kendisine iyi gelmediği ve ailesinin vefat ettiği nedenleriyle buradan tayin olmak için uğraşmaktadır ve 1912'nin Aralık ayında buna muvaffak olur. Kendisi, siyasi propaganda yaptı̆̆ gerekçesiyle görevinden azledilen Dersim İbtidai Müfettişi Hüsnü Efendi'nin görevine tayin edilir. Mehmed Vasıf Efendi'nin yeri ise Kâhta Rüşdiyesi'nden Mustafa Efendi ile doldurulmuştur ${ }^{100}$. Böylelikle rüşdiyenin Besni İbtidaisi çatısı altına gireceği 1913 yılına girilirken Besni Rüşdiyesi'nde muallim-i evvel olarak Mustafa Efendi, muallim-i sani olarak ise Zeki Efendi görev yapmaktadir ${ }^{101}$.

95 Birinci sınıfta 12, ikinci sınıfta 8, üçüncü sınıfta 7 öğrenci ders görmektedir; BOA. MF. İBT., 210/87, (11 C. 1326/11 Temmuz 1908).

96 Birinci sınıfta 9, ikinci sınıfta 12, üçüncü sınıfta 5 öğrenci ders görmektedir; BOA. MF. İBT., 245/50, 14 N. 1327/29 Eylül 1909).

97 BOA. MF. İBT., 238/48, (16 B. 1327/3 Ağustos 1909).

98 BOA. MF. İBT., 344/67, (00 Za. 1329/00 Ekim 1911).

99 BOA. MF. İBT., 357/3, (28 M. 1330/18 Ocak 1912).

100 BOA. MF. İBT., 283/14, (11 Ş. 1328/18 Ağustos 1910); BOA. MF. İBT., 410/62, (4 S. 1331/13 Ocak 1913); BOA. MF. İBT., 410/84, (5 S. 1331/14 Ocak 1913). Mehmed Vasıf Efendi 1911 yılında Gürün Rüşdiyesi muallim-i evvelliğine tayin edilmişse de o sırada başka bir kişinin o göreve atandığ 1 anlaşılınca tayin durdurulmuştur; BOA. MF. İBT., 321/3, (4 Ca. 1329/3 Mayıs 1911); BOA. MF. İBT., 321/27, (4 Ca. 1329/3 Mayıs 1911). Bu durum yetkili makamlar arasında bir kopukluğun olduğuna işaret etmektedir. 


\section{Kâhta Rüşdiye Mektebi}

Çevresindeki Hısnımansur ile Besni’ye göre gelişmişlik ve nüfus yönüyle geride kalmış olan Kâhta, eğitim yönüyle de bu kazalar kadar gelişme gösterememiştir. Kâhta’ya, rüşdiye mektebi açı1ması diğerlerine göre geç gerçekleşmiştir.

Kâhta rüşdiye binası, ülkenin birçok yerinde olduğu gibi yöre halkı tarafından inşa edilmiştir. Bir bab olarak yapılan rüşdiye mektebinin hemen açılarak eğitim-öğretime başlaması için muallimliğe bölge ahalisinden Hacı Ahmed Efendi seçilmiştir. İmtihan tutanakları Maarif Nezareti'ne gönderilen Hacı Ahmed Efendi göreve layık bulunmuş, aylık 250 kuruş maaşla Kâhta muallimliğine tayini tasdik edilmiştir. Maarif Nezareti, vilayete yazdığı yazıyla 80 kuruş aylık ile bir bevvabın istihdam edilmesini ve okulun diğer masrafları için de yıllık 500 kuruş tahsis edileceğini belirtmiştir $^{102}$. Hacı Ahmed Efendi'nin muallimliği 1881 yılının son günlerinde tasdik olduğuna göre okul, salname kayıtlar $1^{103} \mathrm{n} ı n$ da işaret ettiği gibi 1882 tarihinde resmî olarak eğitim-öğretim vermeye başlamış olmalıdır. 21 öğrenci ile başlayan okul, salname verilerine göre, akabindeki yıllarda 31, 37, 30 ve 28 öğrenci ile eğitime devam etmiştir ${ }^{104}$. 1884 yılında Kâhta İdare Meclisi, rüşdiye mektebinde yapılan imtihanlarda öğrencilerin fevkalade başarılı olduğunu yerel gazeteye bildirerek hem muallimi hem de öğrencileri nazara vermiştir: "Saye-i maarifvâye-i cenab-ı tacidâri Kâhta kazası rüşdiye mektebi şakirdanının ale'l-usül imtihanları bil-icra şakirdan muma ileyhin ibraz eyledikleri liyakat ve maharet mucib-i tahsin ve memnuniyet olmuş ve mekteb-i mezkûr muallim-i sanisi Hacı Ahmed Efendi'nin hüsn-i ikdam ve gayreti mekteb-i mezbûrun intizamı delalatiyle mütebeyyin bulunmuş"tur ${ }^{105}$.

Anlaşılacağı üzere idare meclisi, yapılan imtihan sonuçlarını gayet başarılı bulmuş, okulun düzen ve intizamını beğenmişler, okulun varlığından gayet memnun olduklarını ifade etmişlerdir. Aynı y1l, okulu ziyaret eden vilayetten bir heyet, ahalinin okula ilgisini fevkalade bulmuş, ancak bina yönüyle mektebi yeterli görmemiştir. Bu nedenle de okulun yanındaki boş arsa için kaymakam beyle görüşüp yeni bir bina yapılmasının yerinde olacağı düşünülmüştür ${ }^{106}$. Kâhta' daki idarecilerin övgüsünü kazanmış olan Hacı Ahmed Efendi' den sonra ise yerine ulemadan Malatyalı Kalaycızade Mehmed Efendi geçmiştir ${ }^{107}$.

Kâhta halkı ve idarecileri rüşdiye mektebinden memnun olsalar dahi Osmanlı merkezi idarecileri farklı hesaplar yapmaktaydı. Osmanlı Devleti'nin eğitimi modernleştirmeye çalıştığı yıllar, aynı zamanda ülkenin ağır ekonomik şartlarla da mücadele ettiği yıllardı. Dolayısıyla yapılan her icraatın mali karşılığı düşünülmekte daha sonra da yapılan harcamaların beklenen gelişmeyi ne kadar sağladığı kontrol edilmekteydi. 1880'li yılların ortasında mali sorunlarında artmasıyla

102 BOA. MF. MKT., 72/108, (23 M. 1299/15 Aralık 1881).

1031301 tarihli Mamuratülaziz Salnamesinde okulda Muallim olarak Hacı Ahmed Efendi’nin ve öğrenci olarak 21 çocuğun olduğu kaydedilmiştir; bkz. SVM, H. 1301, s. 95.

104 Bkz. Tablo 4; 1885 tarihli bir çizelgede verilen rakamlar salnamelere yaklaşık değerdedir. Buna göre okulun öğrenci mevcudu 1883 yılında 22, 1884 yılında 18, 1885 yılında 33 ve 1886 yılında 40'tır; BOA. MF. İBT., 20/19, (21 C. 1319/5 Ekim 1901). Görüldüğü üzere 1884 yılında az bir düşüş yaşansa da ivme yukarıya doğrudur. Bu rakamlar aslında okulun 1888 yılında kapatılmasının bir hata olduğunu ortaya koymaktadır.

105 Mamuratülaziz Gazetesi, 27 Ş. 1301/21 Haziran 1884.

106 Mamuratülaziz Gazetesi, 1 Z. 1301/21 Eylül 1884.

107 BOA. MF. İBT., 20/68, (1 Ş. 1303/5 Mayıs 1886); SVM, H. 1305, s. 62. 
birlikte, rüşdiye mekteplerinin de gözden geçirilmesi istenmiştir. Buna bağlı olarak da planlandığ 1 üzere yöre halkı çocuklarının istifade ettiği rüşdiyelerin 1slah edilmesi, bekleneni veremeyenlerin ise ihtiyaçları mahalli halk tarafından karşılanıyorsa 1slahı, değilse kapatılması kararlaştırılmışt1 ${ }^{108}$.

$\mathrm{Bu}$ çalışmalardan sonra, hayli zamandır açılmış olmasına rağmen, istenen terakkinin görülemediği gerekçesiyle 1888'ün Ağustos'undan itibaren Kâhta Rüşdiyesi'nin tahsisatı kesilerek mektep lağvedilmiştir ${ }^{109}$. Okulun kapatılmasına yöre halkıyla beraber Mamuratülaziz Valisi de tepki göstermiştir. Vali'ye göre okulun başarısız olduğu tespiti doğru değildir. İlim ve fen öğrenme yönüyle istenen gelişmenin olmamasının nedeni halkın Türkçe diline yabancı olmasıdır. Bununla birlikte, rüşdiye okulu sayesinde ahaliden 40 kadar talebe Türkçe'yi öğrenmiştir. Ancak okul kapatılarak, mevcut öğrenciler ilim ve terbiye ile aydınlanmadan mahrum bırakılmıştır. Ahalisi ekrat ve aşiretlerlerden oluşan Kâhta gibi bölge halklarının aydınlatılması için eğitim, en öncelikli araçtır. Zaten, buralarda okul açmaktan maksat, bu gibi medeniyetten nasibi pek olmayan halkın medeniyet dairesine alınması değil midir? Dilekçesinde bu şekilde serzenişte bulunan Vali Efendi, sözlerinin devamında Maarif Nezareti'ne, Kâhta'da ve buna benzer bölgelerde ilerlemenin hızlı bir şekilde değil, tedrici olarak beklenilmesi gerektiğini ifade etmiş, rüşdiye mektebinin tekrar açılmasını istemiştir. Mekatib-i Rüşdiye İdaresi ise verdiği cevapta, Kâhta Rüşdiyesi'ne ayrılan paranın başka bir yere kaydırıldığından okulun açılmasının şimdilik mümkün olmadığı ve ileride “icabına bakılacağı”nı bildirmiştir"110.

Kâhta Rüşdiye Mektebi lağvedildikten sonra, okulun boşa düşen muallim-i sanisi Mehmed Efendi, 1888 yılında vilayet maarif müdürlüğüne başvurarak Akçadağ Rüşdiyesi’ne ${ }^{111}$, bundan bir sonuç alamayınca 1889 yılında Hısnımansur Rüşdiyesi muallim-i saniliğine tayinini istemiştir ${ }^{112}$. Ancak Mehmed Efendi'nin Hısnımansur'a atandığı ile ilgili bir kayıt bulunamamaktadır. Anlaşılan Mehmed Efendi bir süre daha boşta beklemek zorunda kalmıştır. Bu türlü beklemeler farklı muallimlerin de başına gelen bir durumdu. Örneğin, Arapgir Eskişehir Rüşdiyesi kapatıldıktan sonra boşa düşen Mehmed Vahdi Efendi uzun süre yazdığı dilekçelerle kendine uygun bir muallimlik pozisyonu aramışt ${ }^{113}$. Buradan anlaşılan Maarif yetkilileri okulu kapatmayı düşünürken muallimin nereye tayin edileceğini düşünmemekte, sonrasında gelen dilekçelere göre bir duruma bakılmaktayd1.

Rüşdiye Mektebinin kapatılmasından sonra, bu bölgeden gelen haberler, Dâhiliye Nezareti'ni bazı tedbirler almaya itmiştir. Kâhta ile beraber Akçadağ ve Dersim yöresindeki halkla ilgili "büsbütün zulmet-i cehl içinde kaldıkları"; "fart-1 cehaletlerinden naşi bazı itikadat ve mezahib-i batılaya dahi sülûk eylemiş oldukları" şeklinde gelen haberler, Osmanlı Devleti’nin hassas olduğu noktaların kaşınması gibi idi. Bu nedenle de derhal tedbir alınmalı idi. İşte bu bağlamda Dâhiliye Nezareti, Maarif Nezareti'ne yazdığ seyyar âlimler ve vaizlerin buralara gönderilmesi gerektiğini bildirmiştir. Diğer türlü "cehalet ve dalalette kalmış olan aşair karyeleri”nin bu hallerinin devam edeceği ifade edilmişti. Bu yöre

108 BOA. MF. MKT., 117/56, (18 Ş. 1307/30 Mart 1890); BOA. MF. MKT. 127/49,

109 BOA. MF. İBT., 22/36, (14 M. 1306/20 Eylül 1888).

110 BOA. MF. MKT., 105/90, (26 Ca. 1306/28 Ocak 1889).

111 BOA. MF. İBT., 22/39, (18 M. 1306/24 Eylül 1888).

112 BOA. MF. MKT., 113/41, (19 S. 1307/14 Ekim 1889).

113 BOA. MF. İBT., 196/52, (29 B. 1325/7 Eylül 1907); BOA. MF. İBT., 201/99, (2 Z. 1325/6 Ocak 1908). 
halkının "maarifden hissemend edilmeleri" ve böylece akidelerinin düzeltilmesi ancak, okullar açılması ile âlim ve vaizlerin buralara giderek halka dini meseleleri öğretmesi ile mümkün olabilecekti. Bunun için de gerekli bütçe bulunmalıdır. Gerekirse, maarif-i hisse-i ianesinden, maarif memuru ve rüşdiye muallimi maaşlarından fazla kalan para kullanılmalıdır. Hatta durumun aciliyetine binaen, bu iş için sancaklarda yapılması düşünülen mekteb-i idadilere ayrılan paradan da kullanılabileceği belirtilmiştir ${ }^{114}$.

Bir taraftan cehaletin giderilerek halkın aydınlatılmak istenmesi diğer taraftan yapılacak atılımların mali finansmanının çözümü bu yıllarda bürokratik yazışmaların en önemli konularındandır. Kâhta ile birlikte 10 yere yeniden rüşdiye mektebi açılması meselesi de böyle olmuş; Sadaret, Dâhiliye ve Maarif Nezareti ile Mamuratülaziz Vilayeti arasında süregiden yazışmalara konu olmuştur. Maarif Nezareti'nin bu konuyu vilayete bildirmesi üzerine, Vali Abdülhaluk Nasuhi Bey, vilayetin bir senelik varidatının 400 bin kuruş olduğunu, bunun da zaten yarısının Dersaadet payı olduğunu, 180.352 kuruşun ise maarif memurları ile rüşdiye ve ibtidai mekteplerinin masraflarına harcandığını, 99.400 kuruşun ise idadi mektepleri için ayrıldığını bildirmiştir. Dolayısıyla, toplam varidattan Dersaadet payı gönderilmez ise "vilayette mütemekkin kabail-i ekradın daire-yi münciyye-i itaata ve selamate idhali" için yeniden açılması düşünülen 10 rüşdiye mektebi ile seyyar vaiz ve âlimler için gereken masrafların karşılanabileceğini ifade etmiş̦tir. Vali Nasuhi Bey, ayrıca, Malatya ve Dersim sancaklarına bağlı yerleşim yerlerinde henüz ihtiyaç derecesinde ibtidai ve rüşdiye mektebi olmadığından, buralara idadi mektebi açılmasının erken olduğunu yazmıştır. Maarif Nazırı Ahmed Zühdü Paşa, valinin dilekçesine cevaben, idadi mektebi yapılmasının geciktirilmesi meselesini yerinde bularak, hem böylelikle bütçede 100 bin kuruş fazla paranın olacağını ve bunun ibtidai mektepleri açılmasına kullanılması gerektiğini söylemiştir. Zira ona göre, ibtidai mektebi olmayan yerlerde rüşdiye mekteplerinden bir fayda görülemeyecektir. Ayrıca, seyyar vaiz ve ulema tayininden de Suriye ve Cezayir-i Bahr-i Sefid de olduğu gibi bir semere alınamadığından buna ayrılacak para ile köylere varıncaya kadar ibtidai mektepleri açılmalı; bu ibtidailer mezun vermeye başladıktan sonra ise rüşdiyeler eğitim hizmetine dâhil edilmelidir ${ }^{115}$. Ahmed Zühdü Paşa'nın bu düşüncesinden dolayı Kâhta ile birlikte açılacak 10 rüşdiye mektebi yapımı epey bir zaman gecikmiş; Kâhta Rüşdiyesi ancak 1910'da yeniden açılabilmiştir ${ }^{116}$.

Görüldüğü üzere, Kâhta, çevrenin diğer kazalarına göre rüşdiye mektebine geç kavuşmuş tez ayrılmak zorunda kalmıştır. Dönemin imkânsızlıkları ve devlet adamlarının bu bölge için ibtidai mekteplerini birinci plan almasıyla da tekrar açılması uzun yıllar sonra gerçekleşebilmiştir.

114 BOA. DH. MKT., 1825/16, (23 Ş. 1308/4 Nisan 1891); BOA. DH. MKT., 1862/23, (19 M. 1309/25 Ağustos 1891).

115 BOA. ŞD 211/48, (2 B. 1309/1 Şubat 1892).

116 Mamuratülaziz Gazetesi, 18 M. 1329/20.01.1911; Bu dönemde özellikle finansman temelli görülen sorunlardan dolayı sadece eğitim kurumları gecikmiyordu. Yine Kâhta merkezine 1907 yılında bir Hükümet Konağı yapmak için inşaat başlanmış, yıl 1909'a geldiğinde hâlâ tamamlanamamıştı. Mamuratülaziz Gazetesi bu olayı şöyle vermiştir: İki sene evvel inşasına başlanılub dikkatsizlik, hamiyetsizlik saikasıyla ikmal edilememiş olan Hükümet Konă̆ı'nın yapılan yerleri dahi hal-i harabiyeye yüz çevirmekde ve vezaif-i resmîye hanelerde ifa edilmekde olduğu aldiğımız bir mektubda ihbar ediliyor. Merkez kaza bulunan böyle bir mevki'de Hükümet dairesinin âdem-i mevcudiyeti memurların kendi hanelerinde imrar-ı zaman etmesi şeref-i hükümeti ne derece noksana düşürdüğü bedihidir..."; Mamuratülaziz Gazetesi, 13 L. 1327/14 Teşrin-i sani 1325, s. 2-3. 
Tablo 5. Salname Kayıtlarına Göre Kâhta Rüşdiyesi Personel ve Öğrenci Sayısı

\begin{tabular}{|l|c|c|c|}
\hline Yll & M sani & Bevvap/Hademe & Talebe \\
\hline $1883^{50}$ & Hac1 Ahmed Ef. & Abdurrahman Ef. & 21 \\
\hline $1884^{51}$ & Hac1 Ahmed Ef. & Abdurrahman Ef. & 31 \\
\hline $1886^{52}$ & & & 37 \\
\hline $1887^{53}$ & & & 30 \\
\hline $1888^{54}$ & Mehmed Ef. & Abdurrahman Ef. & 28 \\
\hline
\end{tabular}

II. Meşrutiyet Devri'nde, 1909 yılında, alınan kararla ${ }^{117}$, 1910 yılında yeniden açılan Kâhta Rüşdiye Mektebi'ne 500 kuruş maaşla Çemişgezek muallimi Halil Efendi, muallim-i evvel olarak atanmıştır $^{118}$. Okulun muallim-i evvellik seviyesinde açılması Kâhta Rüşdiyesi'nden beklentinin yüksek olduğuna işaret etmektedir. Halil Efendi'den sonra ise 28 Mart 1911'de Dersim Rüşdiyesi muallim-i saniliğinden Mustafa Efendi aylık 500 kuruşla atanmıştır. Hat muallimi olarak ise kendisine Muhyiddin Efendi isminde bir zat yardımcı olacaktır. Ancak Mustafa Efendi, kısa zaman sonra tayinini istemiş ve Besni Rüşdiyesi muallimliğine ataması yapılmıştır ${ }^{119}$. Okul, kendisinden beklenen yüksek performansa rağmen bir türlü muallimin birinde uzun süreli istikrar yakalayamamıştır. Mustafa Efendi'nin ayrılmasıyla ise yerine yine aylık 500 kuruş maaşla İsmail Hakkı Efendi tayin edilmiştir. İsmail Hakkı Efendi'nin bundan önce çalıştığı yer bugünkü Bulgaristan sınırları içinde kasaba durumunda bulunan Cuma-i Bala'daki rüşdiye mektebidir. Balkan Savaşı çıkınca İstanbul'a gelmiş; Maarif Nezareti de kendisini Mustafa Efendi'nin yerine 11 Ocak 1913 günü itibariyle Kâhta'da görevlendirmiştir ${ }^{120}$. İsmail Hakkı Efendi ve Gilan Rüşdiyesi muallimi Rasim Efendi örneği, Maarif Nezareti’nin Balkan muhaciri muallimlere sahip çıktığını, onlara istihdam oluşturduğunu göstermektedir.

Ancak 1913'ün Şubat ayında göreve başlayan İsmail Hakkı Efendi, aynı yılın Ağustos ayında Kâhta'dan tayin istemiştir. İsmail Hakkı'nın tayin dilekçesi, bir yönüyle muallimlerin neden buradan hemen kendilerini başka bir yere atmak istedikleri konusuna da 1ş1k tutmaktadır. İsmail Hakkı Efendi, dilekçesinde, kendisinin Balkan Savaşı sırasında düşman tarafından istila edilen Köprülü'de bulunduğunu ve sonrasında "Cuma-i Bâlâ gibi medeni ve ma'mur bir kazanın rüşdiye muallim-i evvelliğine mukabil dünyanın en ücra en vahşi bir kazası olan Mamuratülaziz Vilayeti'nin Kâhta Kazası muallim-i evvelliğine tayin" edildiğini yazmıştır. Buna rağmen burada büyük gayret ve fedakârlık gösterdiğini, hatta geldiğinde talebelerin eski usulle eğitim almış olduğunu müşahede ettiğini ancak kendisinin yeni usulle eğitim vererek öğrencilerde büyük inkişaf gösterdiğini ifade etmiştir. İsmail Hakkı bu "harikulade" gelişmeye kaza kaymakamı ve vilayet maarif müfettişinin de şahit olduğunu, hatta maarif müfettişinin "vilayet dâhilinde böyle bir mektep tasavvur dahi edemediğini" dillendirdiğini iddia etmiştir. İsmail Hakkı Efendi, kendisi hakkındaki bu sözlerinden sonra ise yedi çocuğa sahip olduğunu, parasızlıktan dolayı ailesini Kâhta'ya getirmeyip Dersadet'te bıraktığını; bu durumdan kurtulmaları için Dersaadet taraflarında

117 BOA. MF. İBT., 398/64, (10 Za. 1330/21 Ekim 1912).

118 BOA. MF. İBT., 294/60, (24 Z. 1328/27 Aral1k 1910); Mamuratülaziz Gazetesi, 18 M. 1329/20.01.1911.

119 BOA. MF. İBT., 357/3, (28 M. 1330/18 Ocak 1912); BOA. MF. İBT., 410/62, (4 S. 1331/13 Ocak 1913); BOA. MF. İBT., 410/84, (5 S. 1331/14 Ocak 1913).

120 BOA. MF. İBT., 410/70, (4 S. 1331/13 Ocak 1913). 
bir rüşdiye mektebine tayin edilmesini veya ailesinin Kâhta'ya gelmesi konusunda Nezaret'in yardımcı olmasını istirham etmiştir ${ }^{121}$. Kâhta hakkında oldukça olumsuz, kendisi hakkında ise oldukça olumlu intiba oluşturan bu dilekçe sonrasında İsmail Hakkı tatil için Dersadet'e gitmiş, oradayken de Maarif Nezareti'ne tayin başvurusu yapmış ve sonunda Edirne Sancağı dâhilindeki Keşan Rüşdiye Mektebi'ne tayin edilmiştir. İsmail Hakkı'nın tayin isteğinin olumlu karşılandığı Maarif Nezareti evrakında aile durumuna özellikle dikkat çekilmiştir ${ }^{122}$. Bu durum aile birliğinin devletçe önemsendiği şeklinde yorumlanabilir.

$\mathrm{Bu}$ muallim değişmeleri içinde merkeze gönderilmesi gereken öğrenci mevcudunu gösteren hülasa cetvelleri de sürekli aksatılmakta, Nezaret'ten bu konuda uyarı yapılmaktadır ${ }^{123}$. Elimize ancak, 1912-1913 ders yılına ait bir hülasa cetveli geçebildi ki buna göre rüşdiyenin öğrenci mevcudu, birinci ve ikinci sinıfta 5'er ve üçüncü sınıfta 9 olmak üzere toplam 19'dur ${ }^{124}$. Bu sayı aynı zamanda rüşdiyenin kapatılmadan önceki -veya II. Abdülhamid dönemindeki- öğrenci sayısından oldukça uzak olduğunu göstermektedir.

$\mathrm{Bu}$ ders yılının sonunda, 14 Ağustos 1913 'te okuldan ayrılan İsmail Hakkı Efendi'nin yerine ise 21 Ağustos 1913'te bugünkü Kosova bölgesinde yer alan Gilan Rüşdiyesi muallimi Rasim Remzi Efendi atanmıştır. Rasim Efendi Kâhta'ya geldikten sonra, Maarif Nezareti'ne bir dilekçe yazarak kendisinin Gilan'da iken aylık 600 kuruş maaş aldığını, burada ise muallim-i evvel maaşının aylık 500 kuruş olduğunu öğrendiğini belirtmiş, bu durumda kendinin tenzil-i maaşa uğramasının mağduriyet oluşturduğunu, dolayısıyla bu durumun sslah edilmesi gerektiğini ifade etmiştir. Ancak Maarif Nezareti, Vilayet Maarif Müdürlüğü'ne yazdığı cevap yazısında, şu an bunun mümkün olmadığını ancak vilayet hususi bütçesi hazırlanırken kendisinin nazar-1 dikkate alınmasını rica etmiş̧ir. Rasim Remzi Efendi olumsuz cevaptan kısa bir süre sonra 11 Ekim1913’te Kâhta Rüşdiyesi'ndeki görevinden istifa etmiştir ${ }^{125}$. Maarif Nezareti, bunun üzerine yeni bir muallim bulunması için vilayete yazı göndermiş̧tir ${ }^{126}$. Rüşdiyelerin tarih olacağ yıl içinde yeni bir muallim tayin edilmiş midir, bunun cevabını bulamadık ancak; Kâhta Rüşdiyesi bize, eğitimde modernleşmenin, muallim sorunu/muallimlerin sorununu çözmeden ne kadar güç olduğunu bir kez daha ortaya koymuştur.

\section{Sonuç}

19. yüzyılda Osmanlı Devleti'nin gerçekleştirdiği modernleşme hamlelerinin yaşandığg alanların başında eğitim gelmektedir. Eğitimde sivil anlamda modernleşme çabalarının ilk görüldüğü kademe ise orta öğretim olmuş; rüşdiye mektepleri, taşrada açılan ilk modern sivil

121 BOA. MF. İBT., 448/43, (15 N. 1331/18 Ağustos 1913); Kâhta ahalisi de dilekçede ne yazdığından haberdar olmasalar da Kahta'yı bu şekilde olumsuz tasvir eden İsmail Hakkı Efendi hakkında pek iyi düşünmemektedir. Zira Kâhta Kaymakamlığı'nın hazırladığı raporda İsmail Hakkı Efendi hakkında "laubali ve fesada meyyal" ifadesi kullanılmıştır; BOA. MF. MKT., 1188/52, (29 Ş. 1331/3 Ağustos 1913). Anlaşılan bir yerde kendini sevdirebilmek için orayı gerçekten sevmek lazımdır.

122 BOA. MF. İBT., 453/19, (14 L. 1331/16 Eylül 1913); BOA. MF. İBT., 453/19, (14 L. 1331/16 Eylül 1913); BOA. MF. İBT., 453/73, (19 L 1331/21 Eylül 1913); BOA. MF. İBT., 458/3, (7 Za. 1331/8 Ekim 1913).

123 BOA. MF. İBT., 409/4, (20 M. 1331/30 Aralık 1912).

124 BOA. MF. İBT., 445/20, (28 Ş. 1331/2 Ağustos 1913).

125 BOA. MF. İBT., 460/78, (21 Za. 1331/22 Ekim 1913); BOA. MF. İBT., 471/25, (12 M. 1332/11 Aralık 1913); BOA. MF. İBT., 476/11, (8 S. 1332/6 Ocak 1914).

126 BOA. MF. İBT., 476/11, (8 S. 1332/6 Ocak 1914). 
mektepler olmuştur. 1869 Maarif-i Umumiye Nizamnamesi ile taşra sathına yayılması konusunda yapılan planlama kısa zamanda sonuç vermeye başlamıştır. Bu tarihten kısa bir zaman sonra açılan rüşdiyeler arasında 1871 yılında açılan Besni ve 1874 yılında açılan Adıyaman rüşdiyeleri de bulunmaktadır. Kâhta kazasında ise 1882 yılında rüşdiye mektebi açılmış ise de 6 yıllık bir eğitim öğretim hizmetinden sonra kapanmış, tekrar açılması ise 1910 yılını bulmuştur.

Rüşdiye mekteplerinin açılma amacının, birbirleriyle komşu bile olsalar, yöreden yöreye nasıl değişebildiği ele aldığımız üç rüşdiyeyi birlikte değerlendirdiğimizde ortaya çıkmaktadır. Özellikle Kâhta Rüşdiyesi’nin açılması ile ilgili yazışmalara yansıyan "büsbütün zulmet-i cehl içinde kaldıkları"; "fart-1 cehaletlerinden naşi bazı itikadat ve mezahib-i batılaya dahi sülûk eylemiş oldukları" gibi ifadeler bunun en belirgin göstergesidir. Yine üç rüşdiyeyi kuruluş tarihi ile mukayese ettiğimizde yöre halkının katkısının ne kadar değerli olduğunu Besni Rüşdiyesi örneğinde görmekteyiz. Diğer iki kazanın rüşdiyesi ile karşılaştırdığımızda Besni Rüşdiye Mektebi hem daha erken bir tarihte açılmış hem de mali açıdan daha az sıkıntı yaşamıştır.

Ülkenin hemen her tarafında yaşanan sıkıntılardan mevzubahis rüşdiyeler deuzak kalamamıştır. Hem liyakatli muallim bulunması hem bu muallimlere düzenli olarak maaşlarının ödenmesi konusu rüşdiyelerin tarihe karışacağı döneme kadar tam olarak çözüme kavuşturulamamıştır. Özellikle muallim maaşları meselesi Maarif Nezareti yazışmalarında ön plana çıkmakta, bezen eğitim öğretim konularının önüne geçmektedir. Maaşlarını düzenli olarak alamayan muallimler arasında devletin ve padişahın merhametine sığınarak dilekçe üstüne dilekçe yazanlar olduğu gibi, Kâhta Rüşdiyesi muallimi Rasim Remzi Efendi gibi istifa yolunu seçenler de olmuştur. Bu durum eğitimde modernleşme çabalarının hangi şartlarda icra edildiğini göstermektedir. Bununla birlikte aksamalar yaşansa da devletin muallimlere düzenli bir maaş vaat etmesi, maaşların Ziraat Bankası'ndan ödenmeye başlanması, Kâhta Rüşdiyesi muallimi İsmail Hakkı örneğinde görüldüğü gibi aile birliği özrü dikkate alınarak tayin işlemlerinin yapılması geleneksel dönemle mukayese edildiğinde oldukça modern uygulamalardır.

Hâsılı eğitimde modernleşme çabaları oldukça sınırlı imkânlarla yürütülmeye çalışılmış, bu konuda önemli problemlerle karşılaşılmıştır. Bununla birlikte bu problemler karşısında büyük bir mücadele verilmiş ve bilhassa yöre halkının desteğiyle önemli mesafeler de alınmıştır. Adıyaman, Besni ve Kâhta kazalarında açılan rüşdiyeler de bu anlamda kayda değer çabaların görüldüğü mekteplerden olmuştur.

\section{Kaynakça}

\section{Arșiv Belgeleri ${ }^{127}$}

Başkanlık Osmanlı Arşivi, Babıâli Evrak Odası (BOA, BEO).

Başkanlık Osmanlı Arşivi, Dahiliye Nezareti Mektubi Kalemi (BOA. DH. MKT).

Başkanlık Osmanlı Arşivi, Maarif Nezareti Heyet-i Teftişiye Kalemi (BOA. MF. HTF).

Başkanlık Osmanlı Arşivi, Maarif Nezareti Tedrisat-ı İbtidaiyye Kalemi (BOA. MF. İBT).

Başkanlık Osmanlı Arşivi, Maarif Nezareti Mektubi Kalemi (BOA. MF. MKT).

Başkanlık Osmanlı Arşivi, Şura-yı Devlet Evrakı (BOA. ŞD).

127 Arşive ait belge numaraları kullanıldıkları yerlerde gösterildiğinden buraya alınmamıştır. 


\section{Resmi Yayınlar ve Gazeteler}

Maarif-i Umumiye Nezareti Celilesi İdaresinde Bulunan Mekatib-i İbtidaiye, Rüşdiye, I'dadiye, Aliye ile Mekatib-i Hususiye ve Ecnebiyyenin ve Dersaadet'te Tahriri Icra Kllınan ve Taşrada mevcud Bulunan Kütübhanelerin İstatistiği (1310-1311), Dersaadet, Matbaa-i Amire.

Maarif-i Umumiye Nezareti İstatistiki (1311-1312), Darul-Hilafetül'Aliyye, Matbaa-i Amire.

Sâlnâme-i Devlet-i Aliyye (SDA) 1292, 1297, 1299, 1300, 1302, 1303, 1304.

Salname-i Vilayet-i Diyarbekir (SVD) 1288, 1289, 1290, 1291, 1293, 1294, 1300.

Sâlnâme-i Nezâret-i Maârif-i Umûmiye (SNMU) 1316, 1317, 1318, 1319, 1321.

Salname-i Vilayet-i Mamuratülaziz (SVM) 1301, 1302, 1305, 1307, 1308, 1310, 1312, 1316, 1325.

Mamuratülaziz Gazetesi.

\section{Telif Eserler}

Akyıldız, Ali. Tanzimat Dönemi Osmanlı Merkez Teşkilatında Reform (1836-1856), Eren Yayınları, İstanbul 1993.

Alkan, Mehmet Ö., Tanzimat'tan Cumhuriyet'e Modernleşme Sürecinde Eğitim İstatistikleri (1839-1924), DİE, Ankara 2011.

Atalay, Talip, Diyarbekir Vilayeti'nde Hısnımansur, Kâhta ve Besni, Medeniyetler Kavşă̆ Adıyaman Sempozyumu (8-10 Eylül 2006), Adıyamanlılar Vakfı Yayınları, Adıyaman 2008: 149171.

Çelem, Ramazan, Sicill-i Ahval Defterlerine Göre Malatya Doğumlu Memurlar (1879-1909), Yayımlanmamış Yüksek Lisans Tezi, Gaziosmanpaşa Üniversitesi Sosyal Bilimler Enstitüsü, Tokat 2014.

Demirel, Muammer, “Türk Eğitiminin Modernleşmesinde Rüşdiye Mektepleri”, Türkler, C. 15, Yeni Türkiye Yayınları, Ankara 2002: 64-93.

Fortna, Benjamin C., Mekteb-i Hümayun, İletişim Yayınları, İstanbul 2005.

Karataş, Yakup, "Sultan II. Abdülhamid'in Eğitim Politikalarının Mali Bir Veçhesi: Evkaf-1 Münderisenin Maarife Terki”, Atatürk Üniversitesi Türkiyat Araştırmaları Enstitüsü Dergisi (TAED), Say1: 57, 2016: 1839-1867.

Kodaman, Bayram, Abdülhamid Devri Eğitim Sistemi, TTK Basımevi, Ankara 1999.

Mahmud Cevat İbnü'ş Şeyh Nafi. Maarif-i Umumiye Nezareti Tarihçe-i teşkilat ve icraatı -XIX. Asır Osmanlı Maarif Tarihi. (Haz. Taceddin Kayaoğlu). Yeni Türkiye Yayınları, Ankara 2001.

Nalc1, Ahmet - Gün, Doğan, "Modernleşme Yolunda Osmanlı Devleti Maarifinin Finansman Sorunu: Malatya Rüşdiyesi Örneği”, History Studies, C. 10, S. 1, Şubat 2018: 101-123.

Nurdoğan, Arzu M., Osmanlı Modernleşme Sürecinde İlköğretim (1869-1922), Yayımlanmış Doktora Tezi, Marmara Üniversitesi Sosyal Bilimler Enstitüsü, İstanbul 2005.

Öztürk, Cemil, Rüşdiye, İslam Ansiklopedisi, Cilt 35, TDV Yayınları, Ankara 2008: 300-303. 
Öztürk, Said, “Osmanlı Döneminde Adıyaman'ın Sosyal ve Ekonomik Özellikleri”, Medeniyetler Kavşă̆ Adıyaman Sempozyumu (8-10 Eylül 2006), Adıyamanlılar Vakfı Yayınları, Adiyaman, 2008: 117-147.

Pakalın, Mehmet Zeki, Osmanlı Tarih Deyimleri ve Sözlüğü, C. 3, Milli Eğitim Bakanlığ1 Yayınları, İstanbul 1983.

Somel, Selçuk Akşin, Osmanlı 'da Eğitimin Modernleşmesi (1839-1908), İletişim Yayınları, İstanbul 2015.

Ünal, Uğur, II. Meşrutiyet Öncesi Osmanlı Rüşdiyeleri (1897-1907), TTK, Ankara 2015.

Yıldız, Hatip, Diyarbekir Vilayeti'nde Eğitim (1870-1920), Yayımlanmış Doktora Tezi, Atatürk Üniversitesi Sosyal Bilimler Enstitüsü, Erzurum 2007.

(Tablolar içerisinde kullanılan dipnotlar)

1 SVD, H. 1292, s. 129, Sâlnâme-i Devlet-i Aliyye (SDA), H. 1292, s. 158; 1288, 1289 ve 1290 tarihli Diyarbekir salnamelerinde Hısnımansur Rüşdiyesi’nin ismi yer almış, ancak muallimin tayin olmadığı belirtilmiştir. 1291 yılı salnamesinde ise hiçbir kayıt yer almamaktadır; bkz. SVD, H. 1288, 1289, 1290, 1291.

2 SVD, H. 1293, s. 143.

3 SVD, H. 1294, s. 137.

4 SVD, H. 1300, s. 90; SDA, H. 1300, s. 211; Devlet Salnamesi, sadece ögrenci saylsina yer verirken, Diyarbekir Salnamesi'nde ise, ismini belirtmeden okulun bir muallim-i sani ile idare edildiği yer almıştır.

5 SVM H. 1301, s. 95; Devlet Salnamesi’nde ise öğrenci sayısı 31 olarak verilmiş; bkz. SDA, H. 1301, s. 392.

6 SVM H. 1302, s. 95; Devlet Salnamesi'nde ise öğrenci sayısı bu yıl da yine 31 olarak verilmiş; bkz. SDA, $H$. 1302, S. 414 ..

7 SDA, H. 1303, s. 337.

8 SDA, H. 1304, s. 323.

9 SVM, H. 1305, s.61; Devlet Salnamesi ise aynı yıl için öğrenci sayısını 27 olarak vermiştir; bkz. SDA, H. 1305, s. 249.

10 SVM H. 1307, s. 61; öğrenci sayısına yer verilmemiş.

11 SVM H. 1308, s. 65.

12 SVM, H. 1310, s. 119.

13 SVM, H. 1312, s. 172 ve Nüfus Nezareti K1sm1, s. 20.

14 SNMU, H. 1316, s. 1171.

15 SNMU, H. 1317, s. 1370.

16 SNMU, H. 1318, s. 1543.

17 SNMU, H. 1319, s. 876.

18 SNMU, H. 1321, s. 652.

19 SVM, H. 1325, s. 99.

20 BOA. MF. İBT., 209/39, (15 Ca. 1326/15 Hazian 1908).

21 BOA. MF. İBT., 217/103, (20 Za. 1326/14 Aralık 1908).

22 BOA. MF. İBT., 230/1, (6 Ra. 1327/28 Mart 1909).

23 BOA. MF. İBT., 245/50, (14 N. 1327/29 Eylül 1909).

24 BOA. MF. İBT., 381/21, (16 B. 1330/1 Temmuz 1912).

25 BOA. MF. İBT., 452/48, (12 L. 1331/14 Eylül 1913).

26 SVD, H. 1288, s. 126; öğrenci sayısı ile ilgili şu şerh düşülmüş: işbu mektepler bu sene yapılmış ise de aded-i şakirdanı malum olmadı̆̆ için gelecek sene salnamesine derc ve ilave olmak lazım gelir. 
27 SVD, H. 1289, s. 131.

28 SVD, H. 1290, s. 121.

29 SVD, H. 1291, s. 121.

30 SVD, H. 1292, s. 129; Devlet Salnamesi'nde ise talebe saylsı 29 olarak verilmiş, bkz. SDA, H. 1292, s. 158.

31 SVD, H. 1293, s. 143.

32 SDA, H. 1294, s. 537; SVD, H. 1294, s. 137.

33 SDA, H. 1299, s. 275; H. 1297 ve H. 1298 Devlet Salnamelerinde Hısnımansur Rüşdiye Mektebi yer almışken Besni Rüşdiyesi'nin yer almaması, burada görevli personelin ihmali ihtimalini akla getirmektedir.

34 SDA, H. 1300, s. 211.

35 SVM, H. 1301, s. 95.

36 SDA, H. 1302, s, 414; SVM, H. 1302, s. 95.

37 SDA, H. 1303, s. 337.

38 SDA, H. 1304, s. 323.

39 SVM, H. 1305, s. 62; Devlet Salnamesi'nde talebe saylsı 29 olarak verilmiş; bkz. SDA, H. 1305, s. 249.

40 SVM, H. 1307, s. 61.

41 SVM, H. 1308, s. 66.

42 SVM, H. 1310, s. 121.

43 SVM, H. 1312, s. 174, Nüfus Nezareti Kısm1, s. 19; Salnamede verilen öğrenci mevcudu ile ilgili say1, 1894-1895 hülasa defterlerindeki okul mevcudu sayılarının ortalaması gibidir. Şöyle ki, söz konusu ders yılında hazırlanan 3 farklı 3 aya ait hülasa defterinde gösterilen toplam öğrenci sayısı 38, 40 ve 45’tir; BOA. MF. İBT., 37/68, (17 Z. 1311/21 Haziran 1894); BOA. MF. İBT., 43/85, (16 N. 1312/13 Mart 1895); BOA. MF. İBT., 45/55, (29 Z. 1312/23 Haziran 1895).

44 SNMU, H. 1316, s. 1171.

* Maarif Nezareti Salnamelerinde hademe/bevvab ismi belirtilmeyip sadece sayı verilmiştir.

45 SNMU, H. 1317, s. 1371.

46 SNMU, H. 1318, s. 1543.

47 SNMU, H. 1319, s. 877; 1901-1902 ders yılına ait bir hülasa cetvelinde öğrenci sayısı 30'dur. Buna deftere göre birinci sınıfta 16, ikinci sınıfta 9, üçüncü sınıfta 5 öğrenci okumaktadır; BOA. MF. İBT., 114/110, (8 Z. 1319/18 Mart 1902).

48 SNMU, H. 1321, s. 652.

49 SVM, H. 1325, s. 96; Muallimin ismi Devlet Arşivleri'nde bulduğumuz kaynaklarda Mehmed Vasıf olarak geçmekte iken bu salnamede Mahmud Vasıf olarak kaydedilmiştir. Biz arşiv kayıtlarını esas alarak buraya Mehmed Vasif olarak yazıverd $i k$.

50 SVM, H. 1301, s. 95.

51 SVM, H. 1302, s. 95; Devlet Salnamesinde ögrrenci saylsı 33 olarak verilmiştir; bkz. SDA, H. 1302, s, 414.

52 SDA, H. 1303, s. 337.

53 SDA, H. 1304, s. 323.

54 SVM, H. 1305, s. 62; Devlet Salnamesinde bu ylla ait ögrenci saylsı 35'tir; bkz. SDA, H. 1305, s. 249. 
e-ISSN 2458-7672

https://dergipark.org.tr/tr/pub/jhf

\section{Ekler}

Ek 1. Hısnımansur (Adıyaman) Rüşdiye Binası Keşif Planı

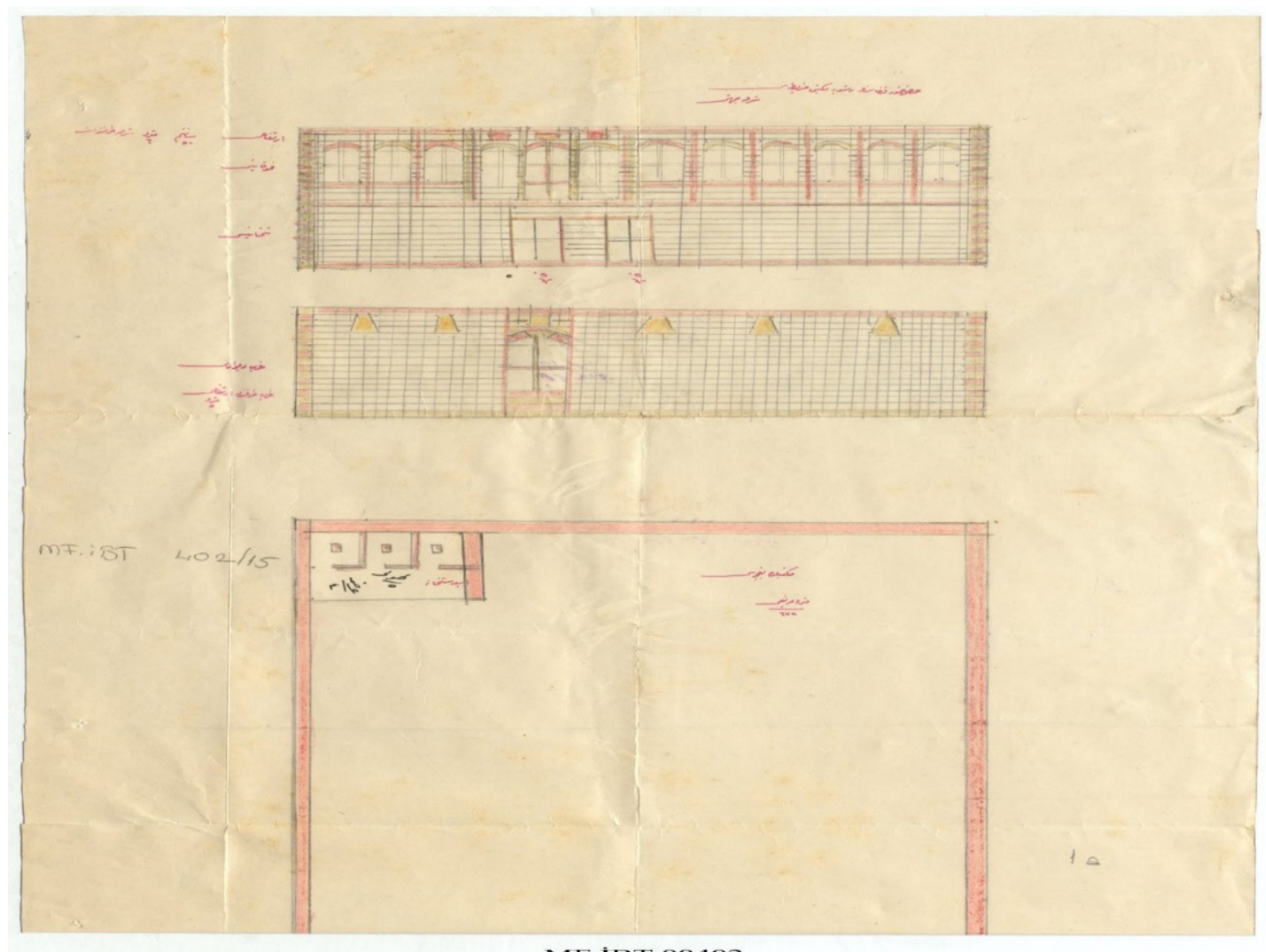

MF.IBT.00402

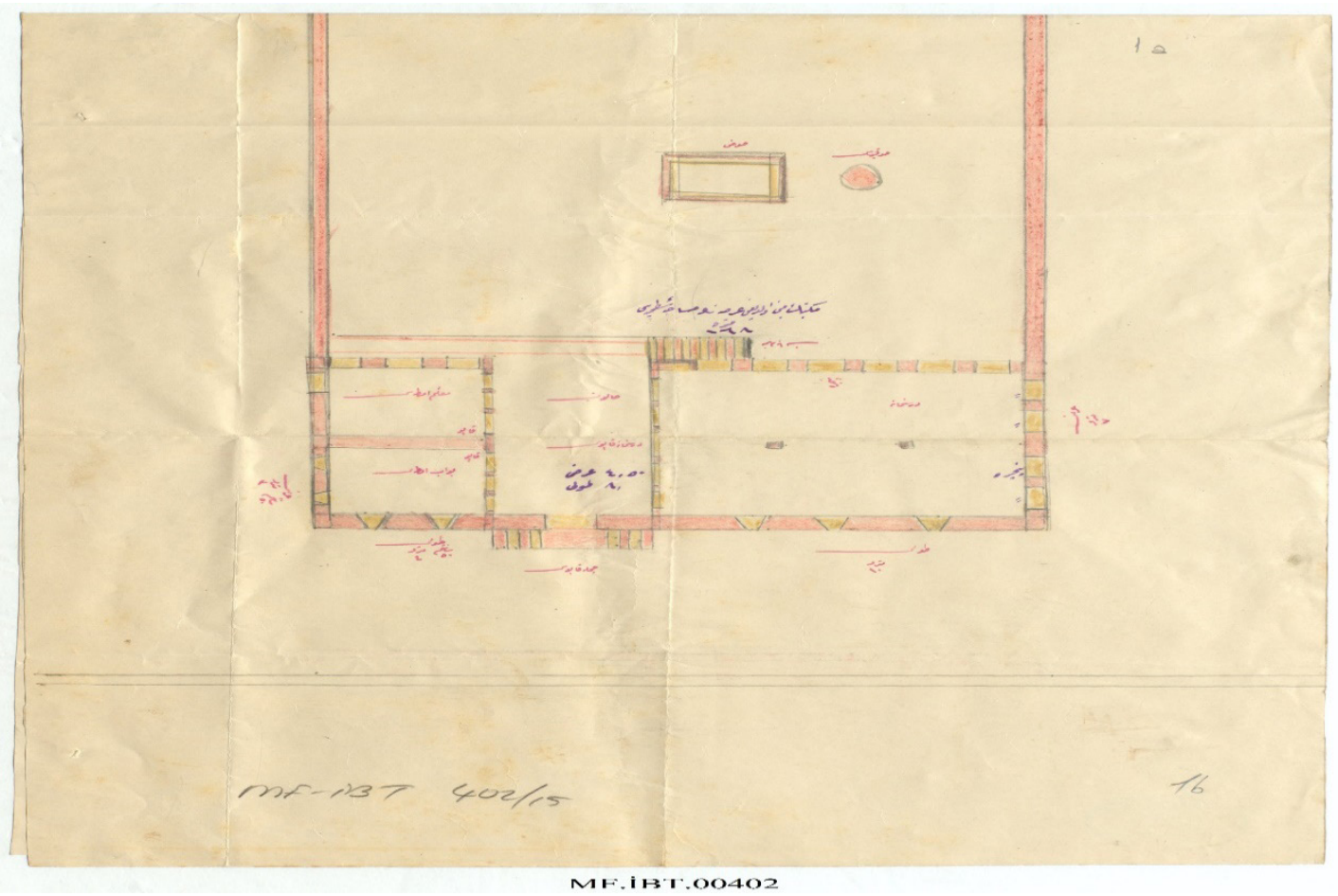


Ek 2. Besni Rüşdiyesi Muallimi Hüseyin Efendi’nin Darülmuallimin Şahadetnamesi

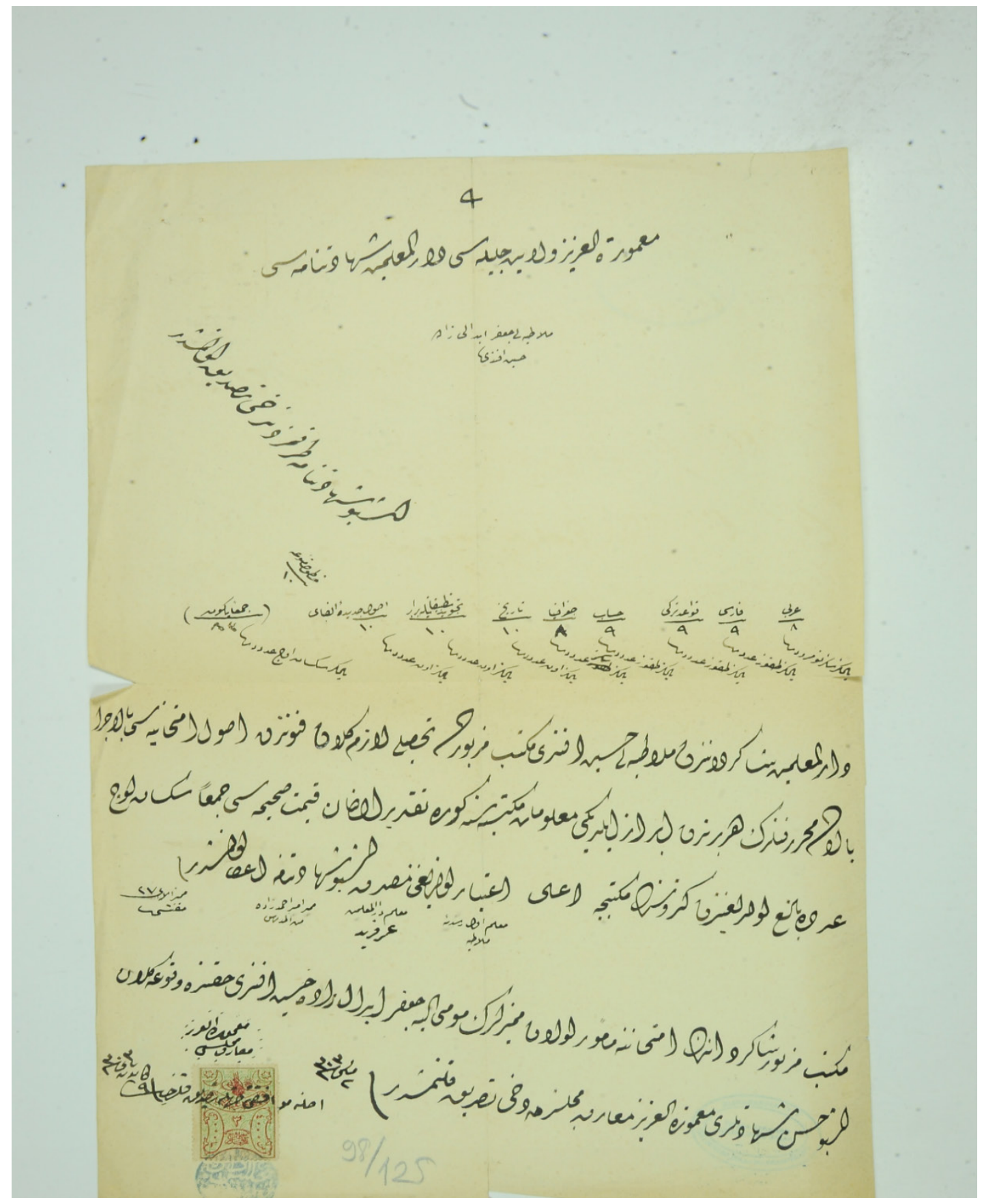

